\title{
Shipwrecks on Roncador Cay, the Caribbean Sea and Their Relationship with Hurricanes, 1492-1920
}

\author{
William Gomez Pretel $^{1} \cdot$ Moon-Soo Jeong $^{2}$ (D)
}

Accepted: 25 May 2021 / Published online: 30 June 2021

(C) The Author(s) 2021

\begin{abstract}
Previous studies suggest that tropical storms and hurricanes are among the leading causes of shipwrecks in the Caribbean Sea since 1492. This paper will explore the relationship between shipwrecks and hurricanes in the Western Caribbean, particularly Roncador Cay, a place with complex environmental conditions that have made this area a trap for ships, but has up until now, been without rigorous shipwreck analysis. This study covers the period 1492 to 1920 with search results of 23 shipwrecks and 37 tropical cyclones compiled in databases, reviewing seven wrecks already documented and revealing new information on 16, previously not recorded. The sources provide detailed shipwrecks, demonstrating that most accidents occurred by unspecific causes and no direct relationship with hurricanes but were influenced by environmental conditions, such as geomorphology, cold fronts, or currents. There is also a reflection on the sociocultural changes and the influence of power in the region. The study includes a suggested tool for future research, protecting the wreck site and emphasizing the importance of the underwater cultural heritage as an indicator of the active maritime past.
\end{abstract}

Keywords Shipwrecks · Hurricanes · Caribbean Sea · Roncador Cay · Underwater cultural heritage

Moon-Soo Jeong

jms@kmou.ac.kr

William Gomez Pretel

wgomezp77@gmail.com

1 International Area \& Cultural Studies, Korea Maritime and Ocean University Graduate School of Korea Maritime and Ocean University, Busan 49112, South Korea

2 Division of Global Maritime Studies, Korea Maritime and Ocean University, Busan 49112, South Korea 


\section{Introduction}

Storm activities and hurricanes are among the leading causes of shipwrecks in the Caribbean Sea (Lugo-Fernández et al. 2007:38; Rappaport and FernándezPartagás 1997:97-98; Trouet et al. 2016: 3173), a place holding a few of the most important Underwater Cultural Heritage $(\mathrm{UCH})$ sites globally (Leshikar-Denton 2002:279). For centuries, cays, banks, and islands in the Western Caribbean have presented a risk for navigators (Herrera y Tordesillas 1601:12-36). The Archipelago of San Andres, Old Providence, and Santa Catalina (ASAPSC) is one of these places in the Caribbean Sea due to its strategic position and environmental conditions that have made this area a trap for ships (Gould 2011: 82-83; Throckmorton 1964: 51-61). A rigorous review of shipwrecks in the archipelago has not been undertaken because parts of the necessary information have either been lost or destroyed during the region's Independence Wars at the beginning of the nineteenth century (Thomas 1974: 346), some accidents were never documented, and pilots (navigation officer) and survivors did not recognize certain places. Also, during colonial times, news on shipwrecks was ambiguous with information disappearing between "Cartagena de Indias and Havana" without an exact revisions of the sites or reported as "lost at sea" (Lugo-Fernández et al. 2007:38), as the case of the galleon Santiago wrecked in 1658 (Fernández-Duro 1899: 437; Serrano 1991:36) or the four galleons of 1605 from the Armada de la Guarda de la Carrera de Indias (Spanish fleet) (Fernández-Duro 1897:253; Segovia 2007).

Located more than 77 nautical miles from Old Providence Island, Roncador Cay is part of the Archipelago. It was given its name by Spanish mariners because of the "snoring" sound produced by constant wave noise, warning of the dangers to navigation, as a deadly trap for ships (Jameson 2010 [1923]:8; Newton 1914:277). One of the first systematic studies on shipwrecks in the region were conducted by Marx (1987), and Romero and Perez (2005) focused primarily on the seventeenth and eighteenth centuries, with a few marine accidents registered in the Cay, but limited information.

This paper aims from quantitative and qualitative research, to explore the relationship between shipwrecks and hurricanes in Roncador Cay from the perspective of underwater cultural heritage, generating a database of shipwrecks and hurricanes (Bryman 2003). Information was collected from archives, databases, and several sources starting from 1492 when hurricanes and shipwrecks were first recorded in the Caribbean Sea (García-Herrera et al. 2007:55; Millas 1968: 300; Vizenor 1991:42) to 1920, considering all wrecks as UCH according to Article 2 of the Colombia Submerged Heritage Law, from 2013, which defined and explained the status of an underwater cultural heritage site and also set a 100-year limitation period for permanently submerged shipwrecks, in addition to other legal aspects provided by the law (Diario Oficial de Colombia 2013). Analysis of data collected on shipwreck events which were permitted as validation of ship loss circumstances, is connected to nautical charts for determining tropical cyclones as the leading cause of ships being wrecked in the Caribbean Sea before 1920 (Chenoweth 2006; García-Herrera et al. 2007; Millas 1968; NOAA 2020; 
Poey 1855). The study will be based on three concepts: validation of shipwrecks with historical hurricanes affecting ASAPSC and nautical charts, non-existence of databases on Roncador Cay, and shipwrecks from different sources.

The research identified 23 shipwrecks with new information of sixteen unrecorded wrecks and reviewed seven others, previously documented by different authors and compiled data on 37 hurricanes reported in the archipelagic waters. Information was classified in databases, analyzing every shipwreck source and its relationships with hurricanes. One of the study's main goals is to unveil UCH's great potential in Colombia and to provide a shipwreck database that does not currently exist in the archipelago. It also suggests a tool for future underwater research recognizing and protecting wreck sites, highlighting past maritime activity, and recovering a forgotten part of maritime history.

\section{Environmental Condition and historical background-Roncador Cay}

The archipelago of San Andres, Old Providence, and Santa Catalina (ASAPSC), is located in the southwest of the Caribbean Sea with approximately $180,000 \mathrm{~km}^{2}$, including the Sea Flower Biosphere Reserve, an extensive coral reef system declared a reserve by the United Nations Educational, Scientific and Cultural Organization (UNESCO) in 2000 (Coralina-Invemar 2012; Mow et al. 2003). The archipelago is an impressive region due to its geography and dispersion of several cays, atolls, and islands of mainly coral and volcanic origin. It is mostly composed of the cays and banks of Roncador, Serrana, Serranilla, Quitasueño, Albuquerque, and Bajo Nuevo, and the largest inhabited islands, San Andres, Old Providence and Santa Catalina (Fig. 1) (Coralina-Invemar 2012; Dimar 2005).

Roncador Cay is $400 \mathrm{~m}$ long and $150 \mathrm{~m}$ wide with a bank of approximately 15 $\mathrm{km}$ long and seven km wide with a unique morphology (Geister and Díaz 2007; Idárraga-García and León 2019; Milliman 1969:13, 14; Nicaragua v. Colombia 2008: 26). The complexity of the region's climate is defined by its tropical location modulated by the Intertropical Convergence Zone (ITCZ) with two seasonal periods determined by precipitation (rainy season-August to November) and northeast trade winds with severe weather events as cold fronts (dry season-December to April). During the dry season, the northeast trade winds dominate the Caribbean Sea with an average speed of 15 knots and diurnal variation peaks up to 30 knots (Andrade and Barton 2000). Also, cold front events strongly impact the archipelago during the first three months of the year, increasing the intensity of the wind, cloud cover and wave height, with an annual average of six events in the area (Ortiz-Royero et al. 2013:2797-2801). The archipelago is highly vulnerable as it is located in the hurricane belt (Ortiz-Royero 2007, 2012:826). This area is impacted by surface currents in the northeast direction (Andrade 2001); however, Serrana Bank and Roncador Cay are influenced by strong currents in the northwest direction (Garay et al. 1988:3-4).

Navigated by Christopher Columbus during his fourth voyage from Jamaica to Honduras (Feiling 2018:7; Vergara y Velasco 1888:76), the archipelago is considered one of the most treacherous areas to sail in the Caribbean Sea (Hernández 

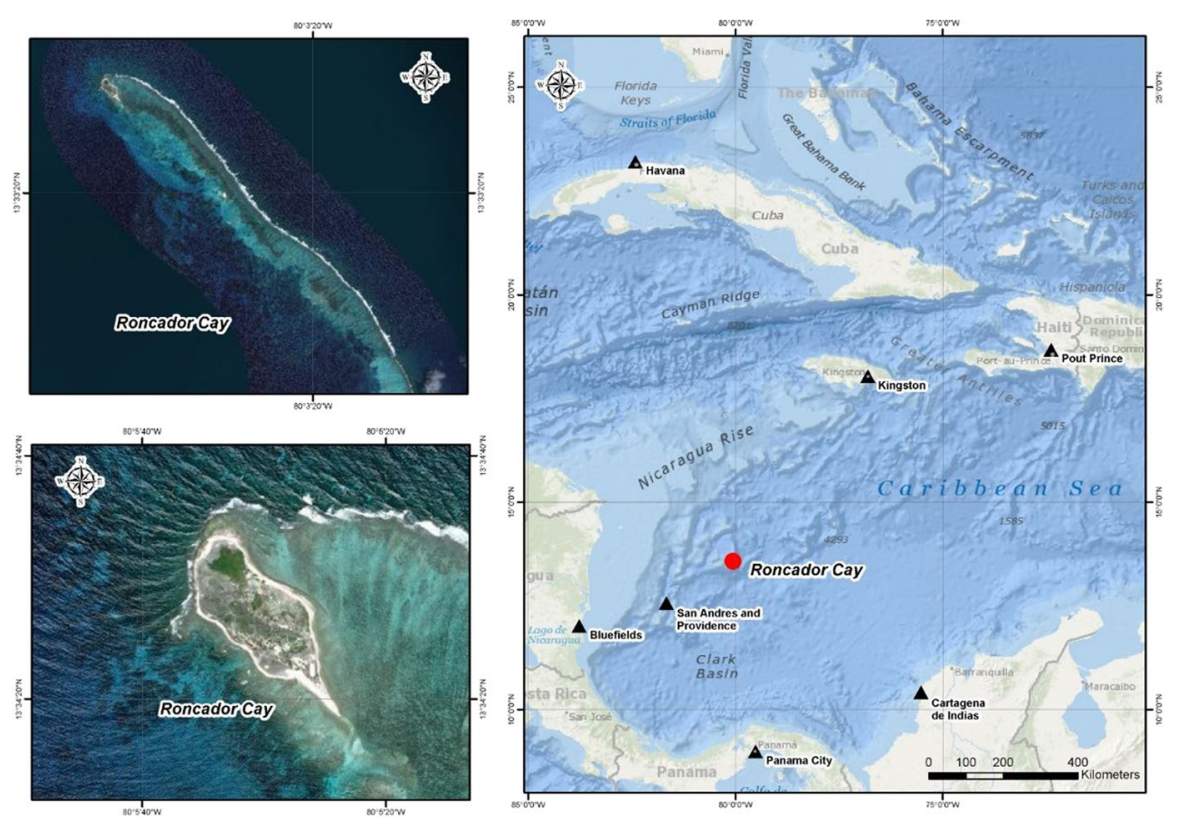

Fig. 1 Map of Roncador Cay and its location in the Caribbean Sea, in one of the main navigation routes, between Central America (Nicaragua and Panama Canal), South America (Colombia), and Jamaica

Oliva 2009: 94; Herrera y Tordesillas 1601:12-36). The complex environmental conditions are the main obstacle for navigators in the region due to its geomorphology with many islands, cays, banks (Gomez-Pretel and Jeong 2020:20; Parsons 1956:4), as well as severe weather events such as cold fronts and tropical cyclones. Also, strong currents may lead to a ship drifting off-course, especially between Roncador Cay and Serrana Bank (Ariza et al. 2018; Coralina-Invemar 2012:36-59; Richardson 2005).

There is no exact information about the discovery of Roncador, but Spanish navigators mentioned it in the early sixteen century with the name "Roncador" (US Department of State, Office of the Legal Advisor 1932) because of the noise made by the breaking wave (Jameson 2010/1923: 8; Newton 1914:277). The first map of the Caribbean made by Juan de la Cosa makes no mention of the archipelago, and it was recognized for the first time in 1529 by Diogo Ribeiro map (Sutton and Yingling 2020; Vigneras 1962). The dangers of sailing from Cartagena de Indias to Havana in the late sixteenth century were described by the cosmographer -chronicler Juan López De Velasco (1894), who highlighted the dangers between Roncador Cay (13 ${ }^{\circ}$ north) to Serranilla Bank (16 ${ }^{\circ}$ north). Also, Herrera y Tordesillas (1601) described this area, warning navigators about the risks and hazards. During the nineteen century, Roncador was known as "the graveyard of the Caribbean" among American navigators and a dangerous area to sail and approach (Hobson 1894:164). 
The Spanish surveyed Roncador Cay in 1804 (Domínguez et al. 2012), but HMS Shearwater questioned its position on the chart, determining eighteen" further eastward and some bathymetric measurements with low accuracy (Purdy 1825:54). After 1828, the British surveyed ASAPSC producing high-quality nautical charts (Figs. 2 and 3) (Allen 1841; Kupperman 1993:355; Gomez-Pretel and Jeong 2020:21).

The area became one of the leading maritime trade routes during colonial times connecting the South American continent with Cuba (Cartagena de Indias - Havana) (Gomez and Carvajal 2011:180; Rowland 1935: 299; Singer 1998:1314), and during the republican period, Panama and the United States (Colón, formerly known as Aspinwall-New York) (McGuinness 2008: 6). The United States claimed Roncador's sovereignty under The Guano Islands Act of 1856 (Burnett 2005), and years later, early in the twentieth century, Japan showed interest in establishing a naval station there (New-York Tribune 1913:2; Parsons 1956:25). Today, this territory belongs to the Republic of Colombia.

Fig. 2 Roncador Cay, 1835. Survey L449 Roncador Bank, surveyed by HMS Thunder. The National Archives of the UK Hydrographic Office Archives. Original copy from 1835 (Korea Maritime and Ocean University Library)

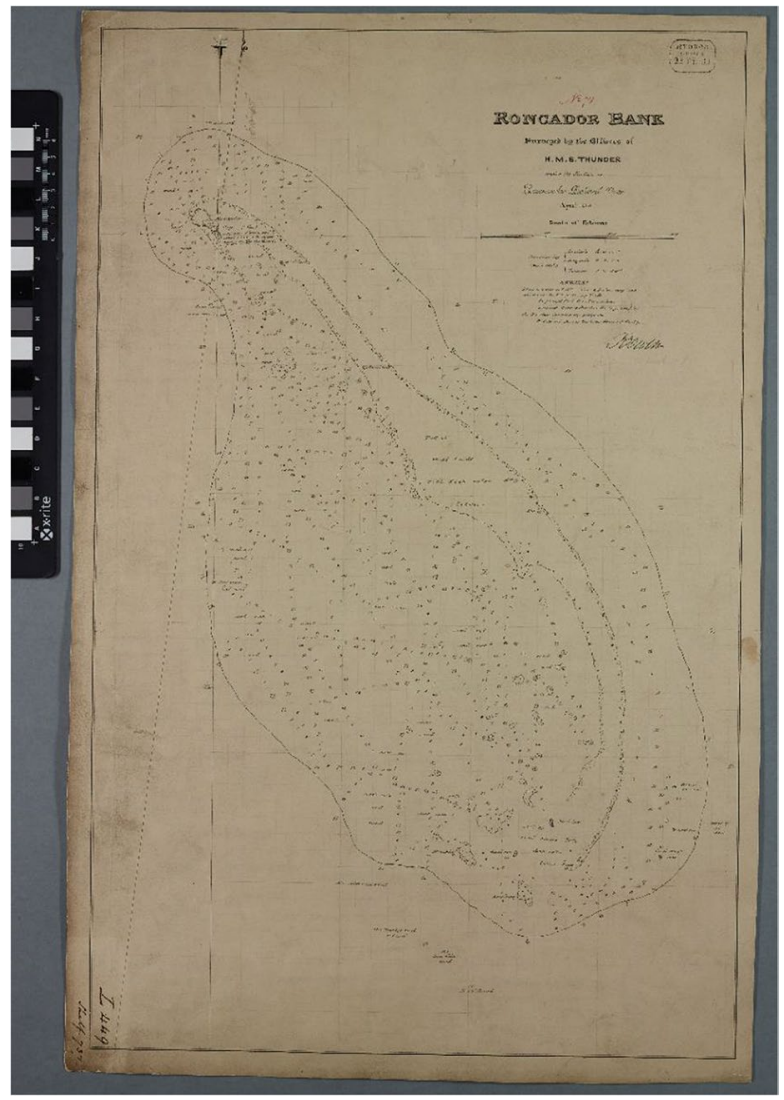




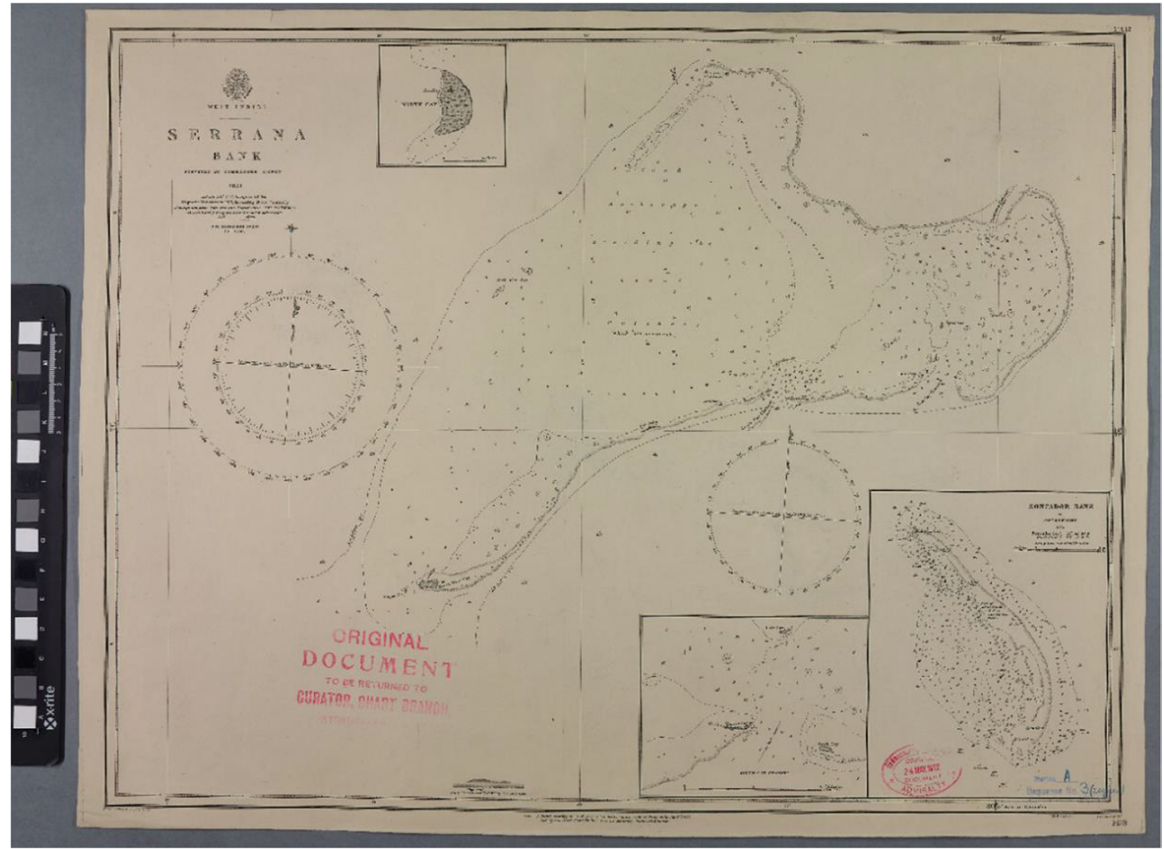

Fig. 3 Serrana Bank and Roncador Bank. OCB 1478-A3 corrected to 1912. The National Archives of the UK Hydrographic Office Archives. Original copy from 1912 (Korea Maritime and Ocean University Library)

\section{Methodology}

\section{Sources for shipwreck identification}

The data collected includes information on warships, galleons, slave ships, merchantmen, privateer ships, and steamships, mostly from digital archives, repositories, databases, libraries containing digitized information and multiple newspapers.

The Archipelago of San Andres, Old Providence, and Santa Catalina has been an important trade route used by three powers in different periods of modern history: Spain, England, and the United States (Brauer 1988; Davis 1973; Leshikar-Denton 2002; Zapatero 1990). For this reason, official information was collected from the archives of these countries such as: Archivo General de Indias-AGI (the General Archives of the Indies), The (UK) National Archives (TNA), The National Maritime Museum (Greenwich, UK), Calendar of State Papers Colonial, America and West Indies (British History Online - BHO), The British Library (historical newspaper section), the (US) National Archives and Records Administration (NARA), and the (US) Library of Congress (LC) - Chronicling America (digitalized newspaper section). Besides these sources, several chronicles and books were consulted in Spanish (Cabrera de Córdoba 1857; Fernández-Duro 1897, 1899; Romero and Perez 2005) and English (Hocking 1969; Larn and Larn 1997; Marx 1987; Sandz and Marx 2006). 
Other sources on shipwrecks were analyzed, such as Lloyd's Register of Ships, as it is considered a primary source of information, with one of the world's most comprehensive databases regarding ship plans, survey reports, classifications, and wrecks in Casualty Returns with records of total losses of vessels worldwide since 1891, even though it is not a government agency (Larn and Larn 1997: 8-9). Some websites with detailed information about shipwrecks were examined, such as Maritime Archaeology Sea Trust (MAST), with the Royal Navy loss list searchable database (MAST 2020) and the UNESCO Underwater Cultural Heritage databases website. This site provides databases elaborated by external institutions worldwide, organized by regions, but without any information from the Caribbean Sea region or Roncador Cay (UNESCO 2020).

Despite the fact that Roncador is within Colombia's territorial waters, much of the information on shipwrecks is declared confidential. Access to coordinates or locations is restricted by Article 17 of the Colombia Submerged Heritage Law, from 2013 (Diario Oficial de Colombia 2013). One of the reasons is UCH's litigation between the government and salvage companies (Zenkiewicz and Wasilewski 2019), as is the case of the galleon San Jose sunk in 1708 during a British attack (Phillips 2007; Phillips et al. 2008).

Data collected during the colonial period was arguably questionable, and news about shipwrecks was minimal. During the Spanish navigation system of Carrera de Indias-Fleet convoy (Díaz Blanco 2018; Singer 1998:13-14), hundreds of galleons were lost in unidentified locations, by the Spaniards, across the whole West Caribbean, from Panama to the Yucatan peninsula, off the coast of Honduras, and by the British, in the West Indies (Lugo-Fernández et al. 2007; Parsons 1956:4-10). The second half of the nineteenth century presents comprehensive information due to the speed of information afforded by the telegraphic cable developing international communication networks (Kennedy 1971), permitting a meticulous analysis of the circumstances, and in some cases, the location of shipwrecks.

\section{Nautical Charts -Data Validation}

Nautical charts provided information about shipwrecks and were used to validate the accidents found during this research. Symbols and abbreviations started to be included by the 1830s under Francis Beaufort (National Library of Scotland 2020), making it valuable to identify wrecks, as is presented in the nautical chart OCB 1334-A2-Old Providence Island published in 1840 by the UK Hydrographic Office with the wreck of the HMS Jackdaw in 1835 (Dawson 1885:126).

The decision to research from 1804 to 1920 was made because nautical charts made before the nineteenth century are considered defective and inadequate to validate shipwrecks. Consequently, five nautical charts were found in the archives of Spain, the United Kingdom, and the United States, produced by these countries (Table 1). These charts were examined in order to find symbols or signs from shipwrecks without any correlative information. However, the first symbol of a wreck was found in the chart OCB 1218 A22, UK Hydrographic Office of 1973 at the south of Roncador Cay without relevance in this study. 
Table 1 Relation of Nautical charts of Roncador Cay for shipwrecks validation

\begin{tabular}{lll}
\hline Year & Nautical Chart & Wreck info. \\
\hline 1804 & $\begin{array}{l}\text { Planos particulares de los Bajos: Las Ranas, Nuevo, Serranilla, Serrana, Ronca- } \\
\text { dor y de los Cayos de tro del Placer de la Vívora. Levantados por D. Joaquin F. }\end{array}$ & No information \\
& $\begin{array}{l}\text { Fidalgo. España (Nautical Chart of Low Islands: Las Ranas, Nuevo, Serranilla, } \\
\text { Serrana, Roncador, and Pedro del Placer de la Vívora Cay by Joaquin F. }\end{array}$ & \\
& Fidalgo. Spain) & No information \\
1835 & $\begin{array}{l}\text { Survey L449 Roncador Bank surveyed by HMS Thunder. UK Hydrographic } \\
1875\end{array}$ & OCB 1478 -A2 corrected to 1875. UK Hydrographic Office \\
1893 & No 1374. Serrana Bank-Roncador Bank. US Hydrographic Office & No information \\
1912 & OCB 1478-A3 corrected to 1912. UK Hydrographic Office & No information \\
\hline
\end{tabular}

\section{Hurricanes in Roncador Cay and the Archipelago}

Many Spanish and British documents provide evidence of hurricanes in the Caribbean Sea as early as 1492, noting that the area had a global significance of weather activity (Chenoweth 2006; Millas 1968), but it was not until the latter half of the nineteenth century, with the acceptance of the Law of Storms, that tropical cyclones were better understood (Naylor 2015:781-782). However, after that time, hurricanes that impacted areas near the archipelagic waters, such as Honduras, Nicaragua, Panama, Colombia, and Pedro Bank in Jamaica, were included in this study.

For the purpose of this research, databases, articles, and books were analyzed (Chenoweth 2006; Cochran 2012; Fernández-Partagás and Diaz 1996; García-Herrera et al. 2005; García-Herrera et al. 2007; Millas 1968; Poey 1855; Rappaport and Fernández-Partagás 1995). Also, the National Oceanic and Atmospheric Administration (NOAA) provides a reanalysis of historical hurricane tracks from 1852 to 2016 online that facilitates research of previous hurricane paths. This tool allows users to choose a location (Roncador in this case) and selected tropical cyclones according to the Saffir-Simpson Hurricane Wind Scale. Willoughby and Rahn (2004), however, stated that hurricane winds damage a radius of 100 to $150 \mathrm{~km}$, so a range of 180 nautical miles was applied to Roncador Cay through the NOAA interactive mapping tool, covering the archipelago and the navigation route in the area (NOAA 2020). With these parameters, hurricanes detected from 1492 to 1920 were classified in a table of four columns with the year, month (as stated in the sources), location affected or impacted (the nearest identifiable place in the area), and sources (Table 2).

\section{Analysis of shipwrecks sources and its relation with hurricanes}

After undertaking research utilizing multiple sources, shipwreck results were analyzed to validate the loss circumstances and details. Later, the identification of hurricanes in the archipelagic waters and the use of nautical charts to explore shipwrecks provided better comprehension of the sources' information, 


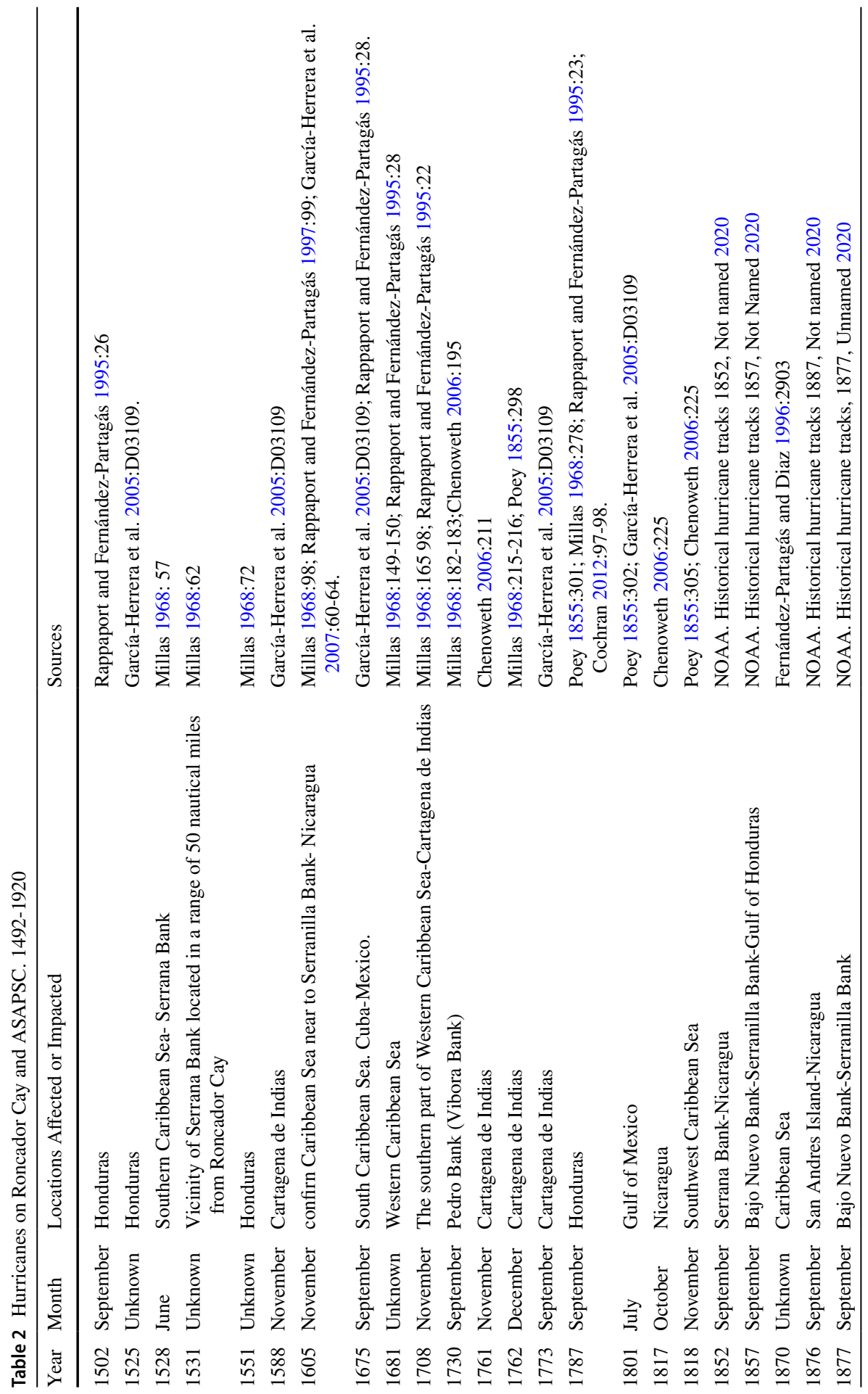




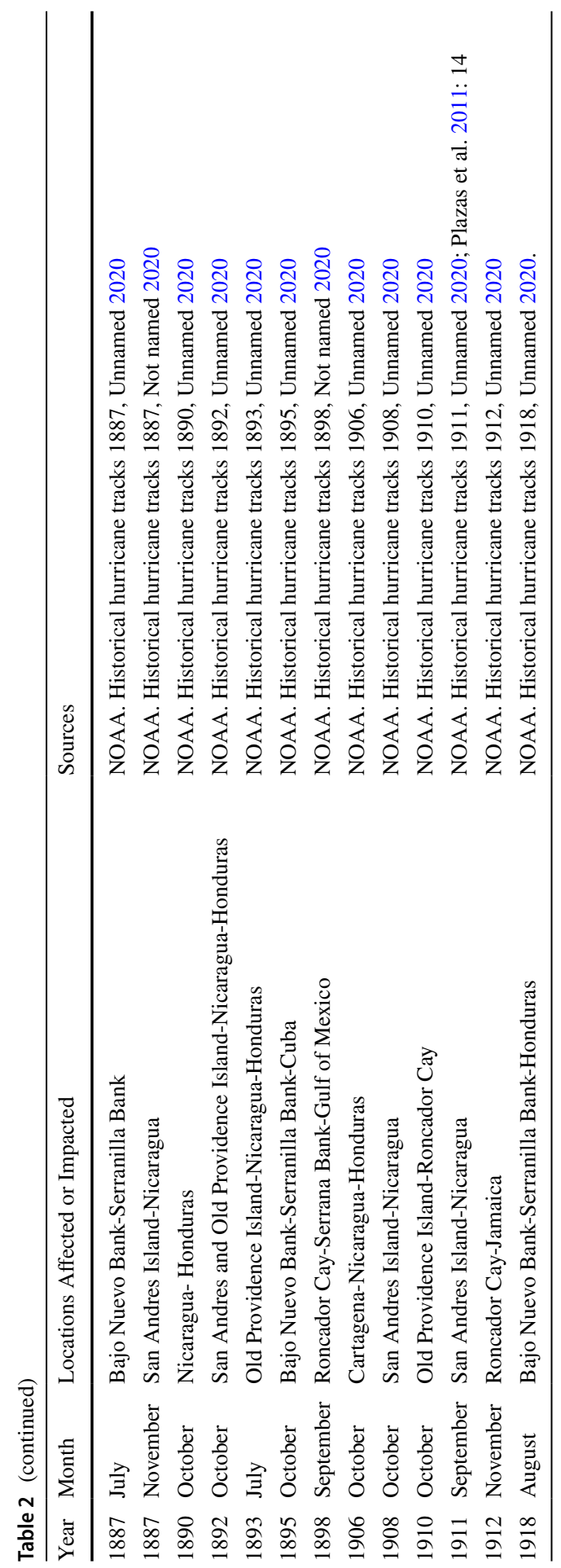


permitting a determination of the relationship between shipwrecks and hurricanes or other causes.

No 1. Unidentified (1531). This shipwreck is based on the narrative of Maestre Juan, a Spanish sailor who was shipwrecked on Serrana Bank in 1528, living there eight years before being rescued. After three years on the island, two men sailed to Serrana Bank on a raft from one of the nearby islands of the 17 described by Maestre Juan around Serrana (Domènech 2020:179-182; Fernández-Duro 2009/1867: 50; Herrera y Tordesilla 1730:83-85; Juan 1782). Juan never clarified where the other shipwreck occurred, but assumed that the ship went down close to the nearest island, Roncador Cay. Uncertainty was generated about the area of this case (Millas 1968: 62), but as Juan was able to communicate with the other men in Castellano (Castilian), it could be presumed that the shipwreck was Spanish. Due to the ambiguous information, the cause of the shipwreck was not determined.

No 2. Capitana-San Roque (November 11, 1605). San Roque was the capitana (flagship) of the Spanish Armada, which was composed of seven galleons (Cerezo 2001:97) and commanded by Captain-General Luis Fernández de Córdoba (Pajuelo 2019:188). The fleet was struck by a hurricane and lost four ships between Serranilla and Serrana Bank, located about 50 nautical miles from Roncador Cay (Fernández-Duro 1897:253; García-Herrera et al. 2007:60-63; Millas 1968:98; Romero and Perez 2005:157; Segovia 2007:188). However, this location is exceptionally ambiguous because the fleet could not estimate their position with celestial navigation instruments due to the weather conditions (Segovia 2007:188).

Added to this ambiguity, some authors debate the year of this shipwreck, occurring between 1604 and 1606 (Fernández-Duro 1897:488). One of the first reports of the incident is from 1605 on a letter to the king from the Governor of Havana, informing him that the galleon San Gregorio reported the fleet was located at $15.5^{\circ}$ between Serrana and Serranilla Bank (Valdés 1605). Other sources documented the ships lost in several places as are the Caribbean Sea (Cabrera de Córdoba 1857:292), on the coast of Honduras (García-Herrera et al. 2007:64; Pajuelo 2019:193), Pedro Bank (Hoyt 1984: 102), Cumana, Venezuela (Pérez-Mallaina 1997:106; Serrano 1991:81), and between Cartagena de Indias and Cuba on an unidentified island socalled the "Mysterious island" described by the Flemish pilot, Simón Zacarías that may be the Swan Islands (Islas Santillana) (Gaspar de Palacios 1688).

Nevertheless, Millas (1968) noted that it was unlikely that tropical cyclones would occur on Venezuela's coasts, determining that it was closer to Serranilla Bank and its surroundings (Millas 1968:98). For that reason, it may be dispersed in the archipelagic waters due to the hurricane intensity (Segovia 2007:200), generating an area of uncertainty, including Roncador Cay, Serrana Bank, Serranilla Bank, and Bajo Nuevo Bank though its location remains undetermined.

No 3. Almiranta-Santo Domingo (November 11, 1605). This galleon was the almiranta (vice-flagship) of the fleet of Luis Fernández de Córdoba along with San Roque (Cerezo 2001:97), and suffered the same consequences as other ships in 
the fleet, from contact with a hurricane (Pajuelo 2019; Segovia 2007). During the marine accident, it was lost in an area of uncertainty near Roncador Cay.

No 4. Nuestra Señora de Begoña (November 11, 1605). Another galleon of Luis Fernández de Córdoba it also suffered the same fate as other ships (Pajuelo 2019; Segovia 2007). Its location is still unknown, generating an area of uncertainty on Roncador Cay.

No 5. San Ambrosio (November 11, 1605). This vessel was also from the fleet of Luis Fernández de Córdoba (Pajuelo 2019; Segovia 2007) and located in an area of uncertainty on Roncador Cay.

No 6. Unidentified (1636). Newton (1914) describes that in 1636, five men stole a shallop boat to escape from the puritan rule in Old Providence Island, pretending to intercept a Spanish frigate patrolling near the Cape Gracias a Dios. However, they shipwrecked in Roncador Cay, and four of them perished. The survivor was rescued by a Dutch merchant vessel near Roncador in February 1639 (Feiling 2018:121; Jameson 2010 [1923]:5; Milliman 1969:14; Newton 1914: 277). The causes of the shipwreck were not identified.

No 7. Santiago (1659). The galleon Santiago apparently was part of the Márquez de Villarubia's Flota de Tierra Firme (Spanish Fleet) sailing between Cartagena de Indias and Havana (Márquez 2018:49). This wreck, along with that of the galleon San Martin, could be in a number of different locations, including the along the coasts of central American countries (Fernández-Duro 1899:437), between Quitasueño and Roncador Bank (Romero and Perez 2005:176; Serrano 1991:36). Márquez (2018) mentioned a wreck on Chinchorro Bank, which may be the Santiago (Márquez 2018:46). Nevertheless, the exact location needs to be clarified, as Roncador Cay is also a debated resting place. The cause of the shipwreck was deemed human error (Serrano 1991:36).

No 8. Unidentified (1675). Marx (1987) described a sizable Dutch warship shipwrecked in Roncador (Marx 1987: 416). Underwater cultural heritage information from the Dutch Cultural Heritage Agency is available through the Maritime Stepping Stones-MaSS and Managing Cultural Heritage Underwater (MACHU), the worldwide shipwreck database, but do not contain any information on this shipwreck (Cultural Heritage Agency 2020). As such, the cause of the shipwreck is not identified.

No 9. El Paysano (1801). This shipwreck was documented in an unspecified area near San Andres Island with the crew lost (Marx 1987: 417). This ambiguous information allowed localizing it in an area of uncertainty near Roncador as the cay is in the vicinity of the island. The causes of the shipwreck were not identified. 
No 10. Dolorita (July 1837). There is documentation of this ship's activities in the Atlantic slave trade coming from the "Havana Slave Trade Commission" (Lovejoy 2016) with illegal movements between Africa and Cuba (Curtin and Klein 1973; Foreign and Commonwealth Office 1837:169; House of Commons 1828:27, 142152). During the marine accident, Dolorita was sailing from Kingston to San Juan de Nicaragua (formerly known as Greytown or San Juan del Norte), and the news was documented in England due to the death of a British citizen (Coventry Herald 1837:4). Even with documented knowledge of this vessel's movements, what caused it to be wrecked has not been established.

No 11. Amity (March 1840). Bard (1855:34-55) wrote of a ship that was wrecked on Roncador Cay when it was sailing to Mosquito Coast. Olien (1988) stated that there are several sources for this story. The most likely is found in "Narrative of a residence on the Mosquito shore, during the years 1839, $1840 \& 1841$ " by T. Young (1842). He described his ship wrecking on a bank (conceivably Roncador Cay) in March of 1840 while sailing from Cape Gracias a Dios to Black River's British settlement on board the schooner Amity with a total loss of the ship (Olien 1988:32; Young 1842:37-51). However, even with the seemingly accurate account of the ship wrecking, the cause has not been identified.

No 12. Clarendon (February 27, 1852). Some newspapers in America reported the vessel being wrecked, but with passengers and crew safe (Mountain Sentinel 1852:1; New-York Daily Tribune 1852:8; New York Times 1852:1; Republic 1852:3). The United States consul in Cartagena de Indias sent a letter that year to the Department of State reporting the accident (American Seamen's Friend Society 1853:86). Lloyd's Register of Ships (1835) has information on the ship's characteristics, however, the reason for the shipwreck were not determined.

No 13. Unidentified (September 1857). This shipwreck has minimal information documented in a newspaper in England as a large vessel lost on Roncador Cay sailing from Greytown (San Juan) but without more details (Northern Daily Times 1857: 8).

No 14. Golden Rule (May 30, 1865). The Golden Rule ran aground (Fig. 4) with 632 passengers and 100 crew members on the cay where they spent ten days in the "most miserable conditions" (Fig. 5) (Harper's Weekly 1865:420; Hopkins 1877:17; Missionary Herald 1865: 231-232; New York Times 1865: 5; Robinson 1907:74-79). The USS State of Georgia and USS. Huntsville rescued the castaways (Naval Historical Center 1976:609). The accident was caused by heavy rain and regional geomorphology (New York Times 1865: 5).

No 15. CC Clark (July 5, 1870). Clark was reported as a total loss on Roncador Cay in the Shipping Section-Marine Disasters of the New York Herald (1870:10) but without more detail. 


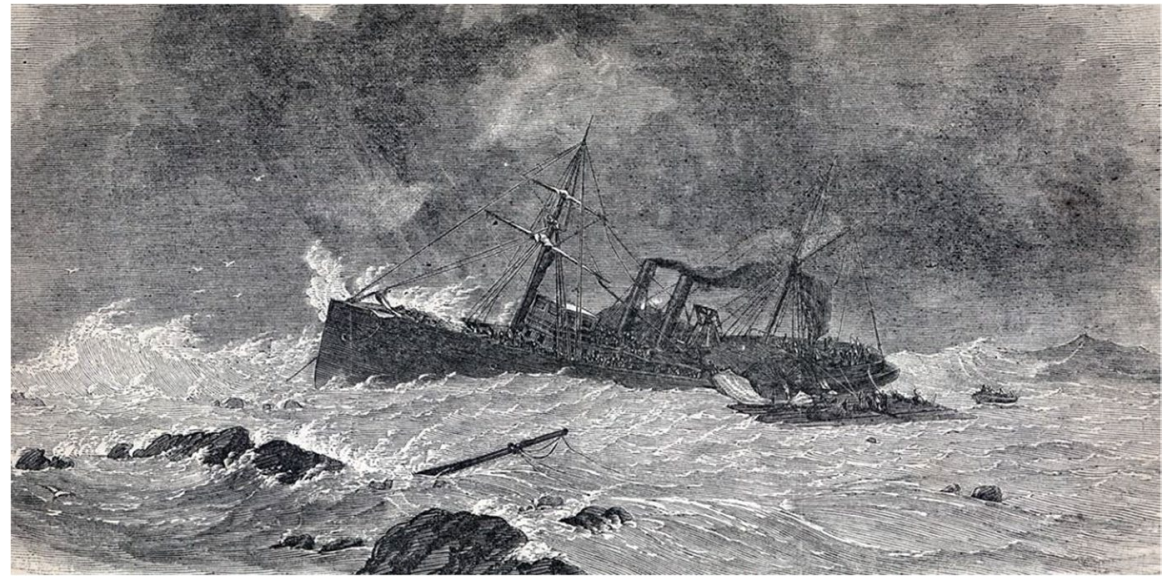

Fig. 4 Wreck of the SS Golden Rule, Caribbean Sea, May 30, 1865, artist's impression. (House Divided: The Civil War Research Engine at Dickinson College 2015a)

No 16. Hiram (February 12, 1886). This Norwegian bark was sailing from Aspinwall, Panama (now named Colón) to Pensacola, Florida (Savannah Morning News 1886a:7) when wrecked on Roncador Cay. After the accident, the crew sailed to Aspinwall in their lifeboats, covering more than 250 nautical miles in 54 hours (New-York Tribune 1886:3). They were transported from Aspinwall by the Pacific

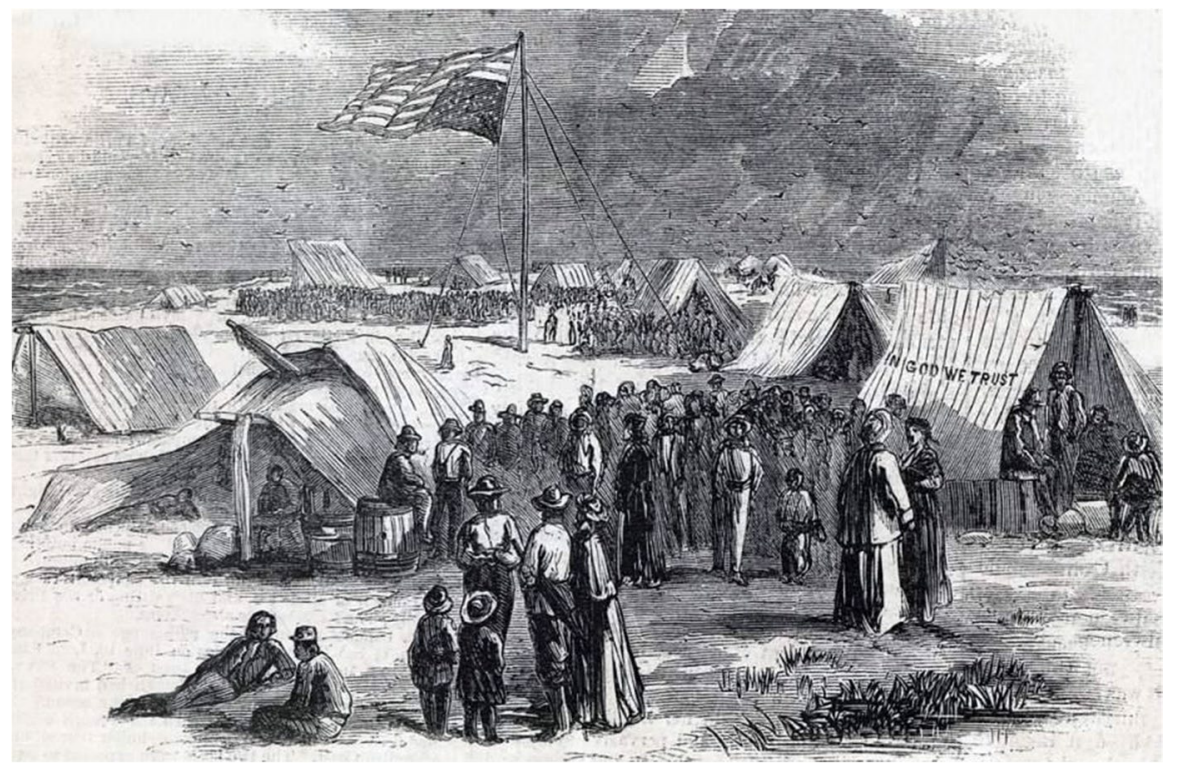

Fig. 5 Survivors of the wreck of the steamer Golden Rule, on Caribbean coral island of El Roncador, May 1865, artist's impression. (House Divided: The Civil War Research Engine at Dickinson Col- 
Mail Steamer City of Para and reported safe in New York (New York Times 1886:5; Savannah Morning News 1886b:7). The reason for the shipwreck was not identified.

No 17. Unidentified (1889). Although there were details in two newspapers covering the wrecks, Aguan in 1891 and the USS Kearsarge in 1894, information about an unnamed steamship wreck on the east side of Roncador was not precise, other than mentioning the crew were safe on San Andreas Island, having made their way there in the ship's boats. The wreck of this steamship was seen by Aguan passengers during their accident two years later (New York Times 1891a, b, c:9; 1894b:2).

No 18. Ydun (February 12, 1890). Little information was reported about the wrecking of the vessel, Ydun, other than The Morning News (1890a, 1890b:3) reporting the cay's name as "Rancador" rather than Roncador. The fate of the Ydun was also mentioned in England without any further details of the accident (New York Times 1894b:2; Shipping Gazette and Lloyd's List 1890:8).

No 19. Aguan (February 26, 1891). This shipwreck was well documented for having onboard Warner Mille, a United States representative and senator from New York, during his trip to Nicaragua for the Canal Project (Evening World 1891:1; Lloyd's Register Casualty Returns 1891:6; New York Times 1891a:1, 1891b:1; New York Times 1891c:9). Spears (1891) makes a detailed account of the shipwreck and the castaway's stay on Roncador Cay before being rescued (Spears 1891:5). The ship's characteristics are available in the "Report for Survey for Repairs" (Lloyd's Register of Ships 1887). The accident was caused by the trade winds and strong currents (Spears 1891:5).

No 20. USS Kearsarge (February 2, 1894). The USS Kearsarge is considered the most famous and glorious ship of the American Civil War, sinking the Confederate State Ship-CSS Alabama, in 1864 (Gomez-Pretel and Jeong 2020:15; Guérout

Fig. 6 USS Kearsarge on Roncador reef. Caribbean Sea, 1894. Photograph of a drawing, by E. H. Hart, 1894, drawn by Chris Johnson, U.S.N. Feb. 3, 1894 on negative (Library of Congress)

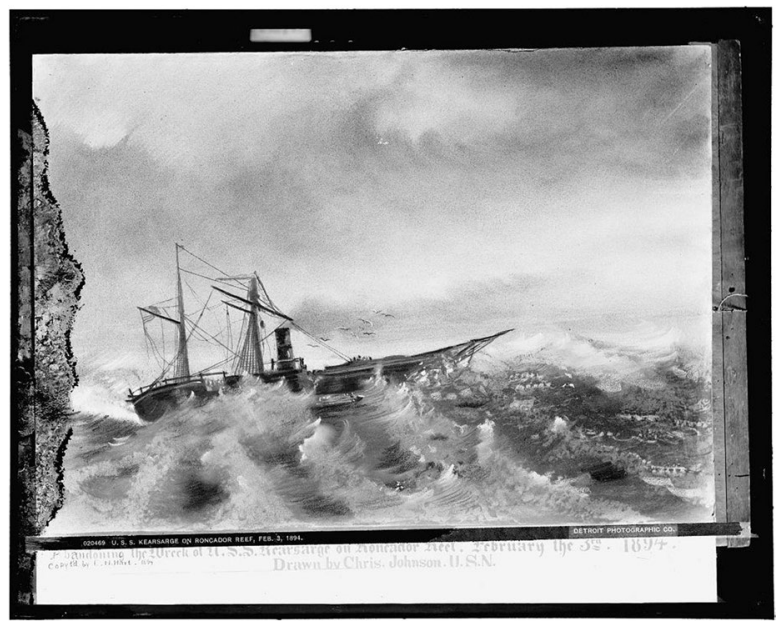


1988; Marvel 2007). After being wrecked on Roncador Cay (Fig. 6) the Kearsarge was abandoned with armaments onboard (seven guns). Primary sources are the Logbook of the USS Kearsarge (Heyerman 1894a), Report from the Commander to the Commander in Chief of the United States Naval Force (Heyerman 1894b) and the court-martial (Lemly 1894; US Hydrographic Office 1894; USS Kearsarge 1894). Other information on the accident and ship characteristics can be found in various articles and books (Burns 1894; Canney 1990:61-90; Dudley 1998:105-109; Hocking 1969:377). The press widely covered this incident which left an indelible mark in the United States, in the US Navy and American society (Dudley 1998; Hobson 1894; New York Times 1894a:1-2). Strong currents to the northwest in a different direction to the vessel's course were blamed for the drift which caused the accident (Burns 1894:672; Gomez-Pretel and Jeong 2020:22-23).

No 21. Kitty (November 19, 1902). A ship from the United Fruit Company was reported as a wreck in "Runcador" by the press (New York Times 1902:6; New-York Tribune 1902:2) and "Roncader" in Casualty Returns (Lloyd's Register Casualty Returns 1902:8). The Kitty was from Norway, and the website Skipshistorie (ship history) has documented characteristics and shipwreck details (Skipshistorie 2017). The causes of the shipwreck were not identified.

No 22. Buckingham (December 12, 1904). The fate of the Buckingham was reported by various newspapers in England (Shields Daily News 1904:3; Western Times 1904:4). Hocking (1969:108) documented this accident on a compilation of disasters at sea. The accident and characteristics of the ship were found on Lloyd's Register of Ships (1897; Lloyd's Register Casualty Returns 1904:7). The causes of the shipwreck were not determined.

No 23. Mayport (January 25, 1920). Reported as a total loss on Roncador Cay during navigation between Norfolk to Colón. (De Tankerville 1920:30; Lloyd's Register Casualty Returns 1920:8; Scotsman 1920:4; Shipbuilding and Shipping Record 1920:148). The causes of the shipwreck were not identified.

\section{Shipwreck Database}

The 23 shipwrecks recorded during this research are presented below in a table (Table 3) with the following information: Ship Number (as per above), Year of Loss (as indicated above), Name of Ship ("Unidentified" where no information was found), Vessel type, Construction material of vessel, Gross Tonnage, Cargo, Vessel's Last Route, Manner of Loss, Location of the Incident (Area of Uncertainty, when the report is not precise), Vessel's Nationality and Reported Casualties. Shipwrecks with no information are shown as Not Available-"N/A." The objective of this database is to serve as a tool for future underwater research in Roncador Cay or the archipelago. 


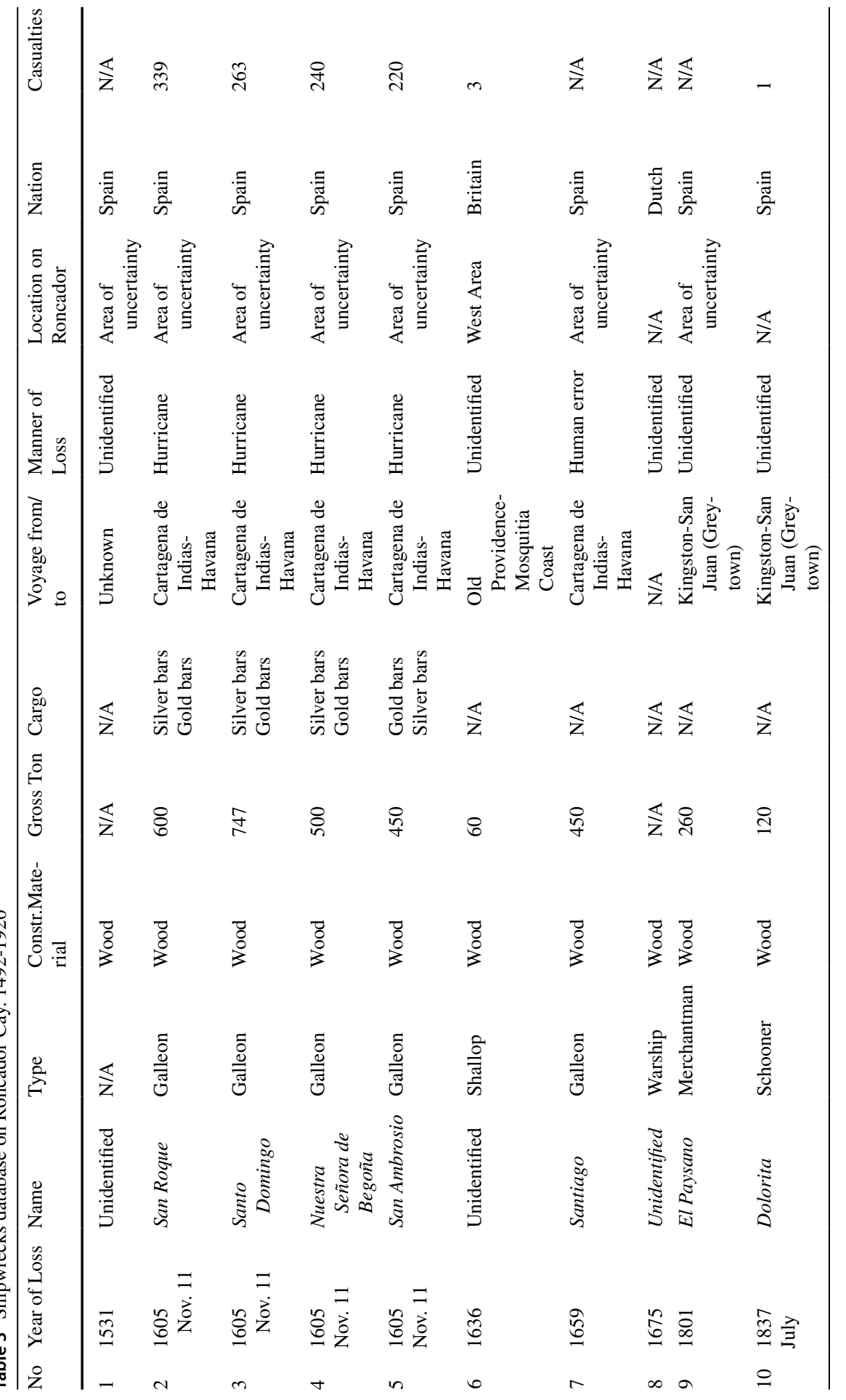




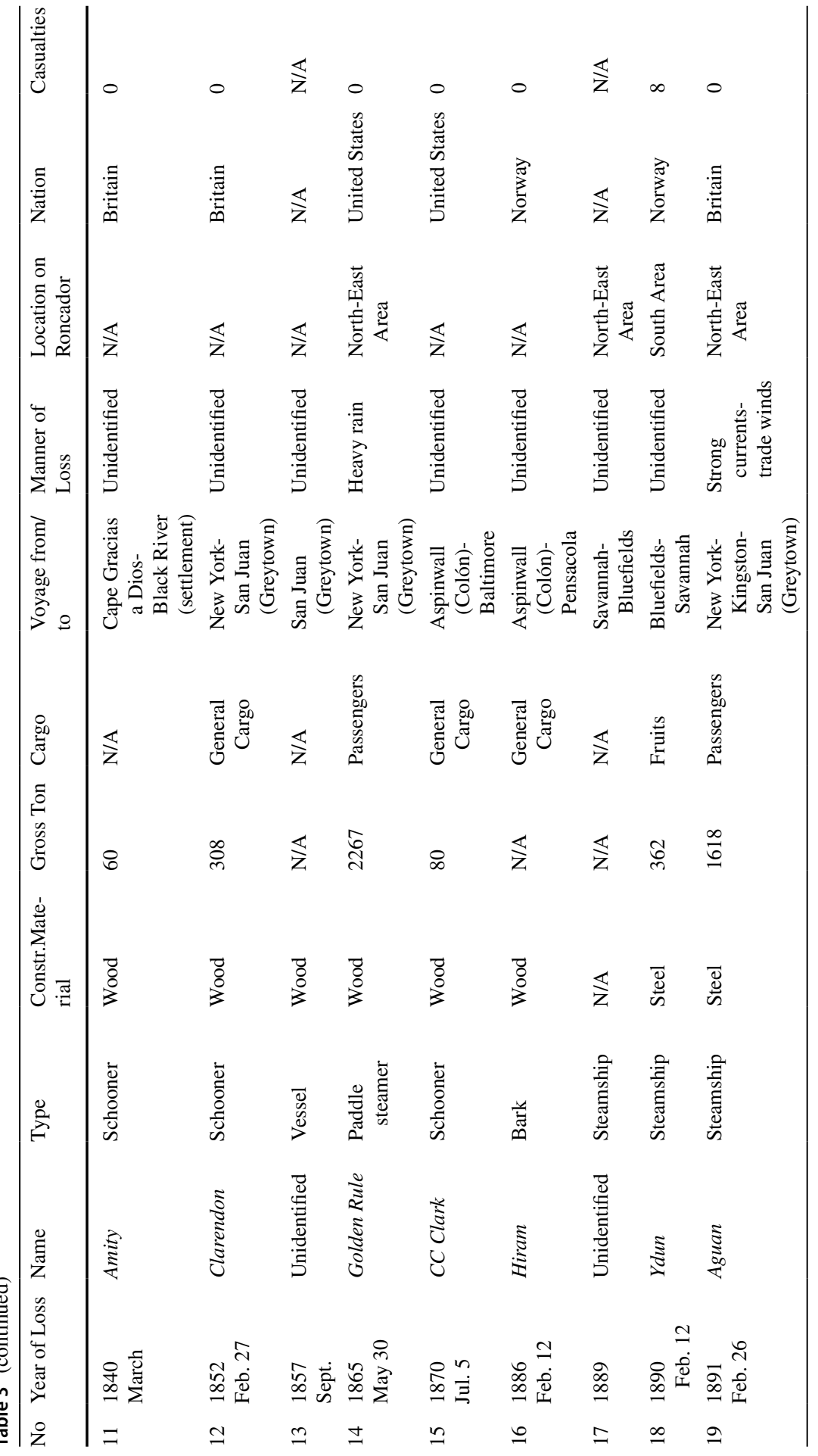




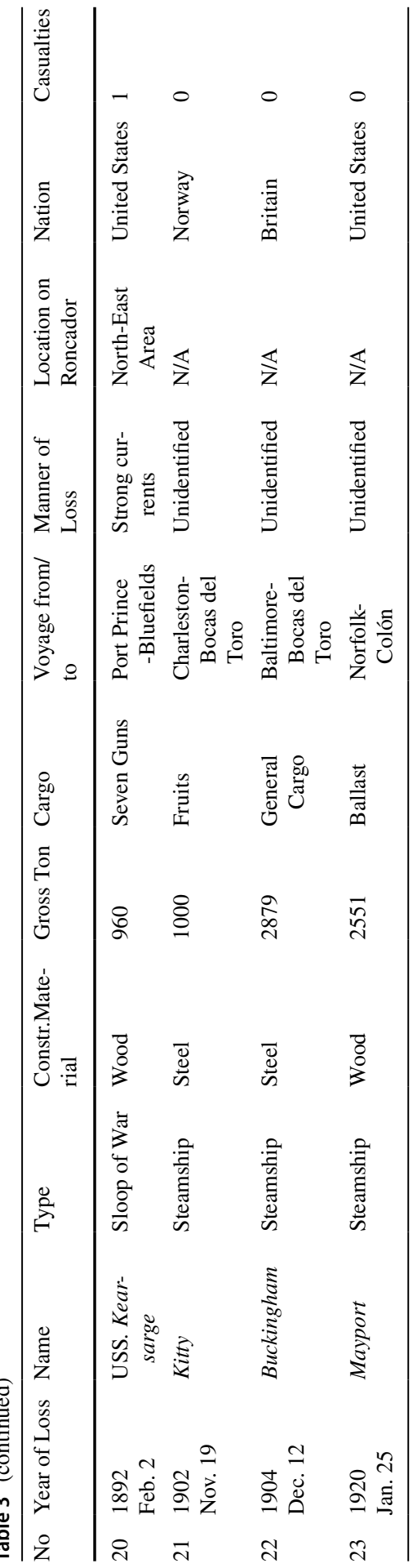




\section{Results}

For the purposes of this study, 23 shipwrecks were classified, and 37 hurricanes were detected from 1492 to 1920 (Fig. 7), including 16 newly-added shipwrecks. The analysis has revealed four accidents caused by hurricanes and three by environmental conditions (regional geomorphology, strong currents, and heavy rain); one by human error and 15 by unidentified causes. Even though García-Herrera et al. (2005), Lugo-Fernández et al. (2007) and Trouet et al. (2016) stated hurricanes as one of the leading causes of shipwrecks in the Caribbean Sea; however, the result of four shipwrecks caused by hurricanes does not support their observation in the area of research. As such, it can be argued that, the findings reveal no correlation between hurricanes and shipwrecks on Roncador Cay.

The sixteenth century had a high frequency of hurricanes (García-Herrera et al. 2005:D03109), but with minimal information on shipwrecks because the region was relatively unknown and without accurate geographical maps (Sutton and Yingling 2020:791-792). During the seventeenth century, the number of shipwrecks detected was high compared with hurricanes (Fig. 7). The colonization process in the Caribbean by the Spanish, and the establishment of a puritan settlement on Old Providence Island in 1629, by the British, are two plausible reasons why the number of shipwrecks increased, during this time (Kupperman 1993:1-2; Rowland 1935:298). In this period, the vessels that suffered from maritime accidents belonged to the Spanish, British, and Dutch representing their presence at the Caribbean Sea (Fig. 8). Hurricane activity in the eighteenth and first half of the nineteenth centuries was very high (Cochran 2012; Poey 1855), but the total number of shipwrecks was low in comparison because of the disruption of maritime trade as a result of the hostilities and wars between Spain and Britain (Phillips 2007) as was the War of Jenkins' Ear (known as Guerra del Asiento in Spain) (Gomez and

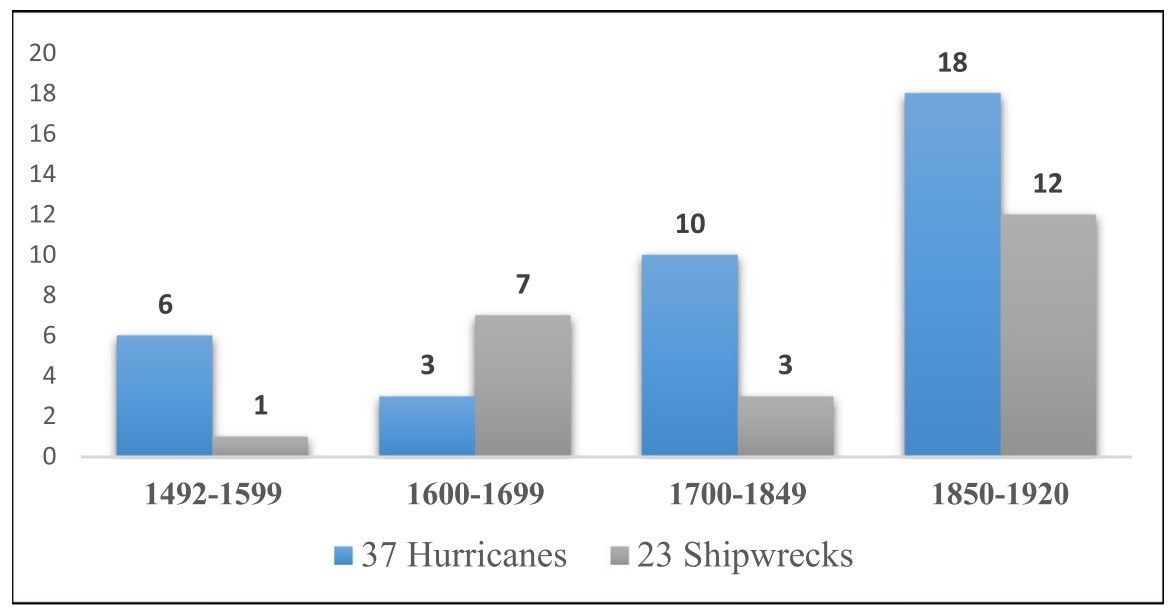

Fig. 7 Shipwrecks and hurricanes from 1492 to 1920. Twenty-three shipwrecks and 37 hurricanes were compiled and classified by centuries and periods (Own elaboration) 


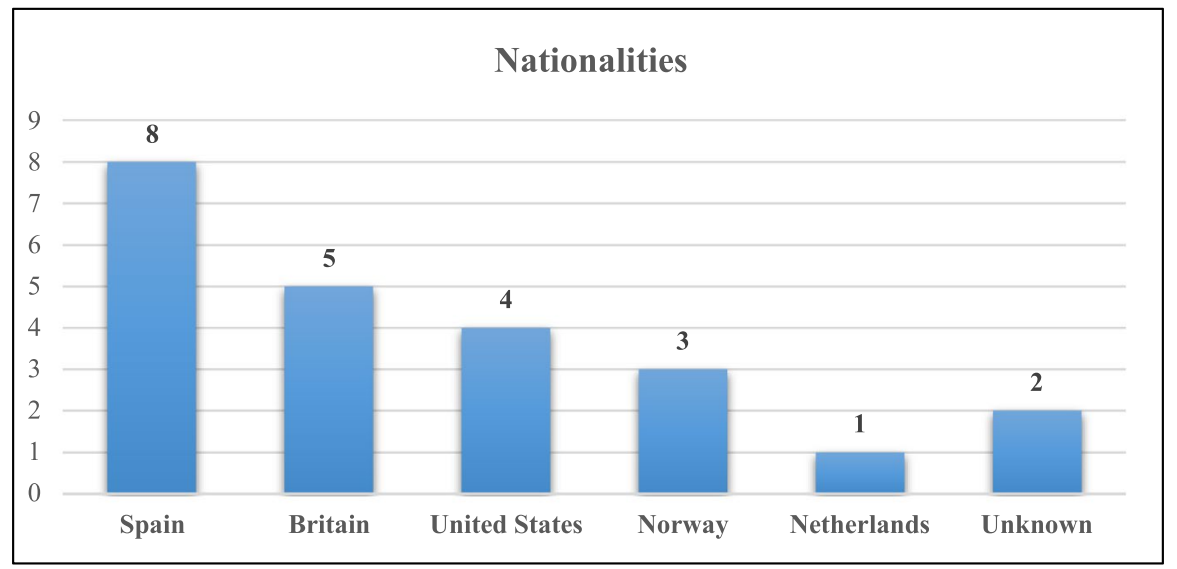

Fig. 8 Countries of shipwrecked vessels 1492-1920. Five countries were detected showing their influence in the Caribbean Sea, and two shipwrecks with no information

Carvajal 2011:180-181; Temperley 1909; Zapatero 1990) and the independence of certain colonies in the Caribbean area (Bosch 2009).

The last period covered (1850-1920), saw the highest frequency of events detected, with many reasons for this. On the one hand, technology allowed better and faster communications (Kennedy 1971:728); while on the other hand, new navigation routes were activated by Americans, to and through Panama during the California Gold Rush (Kemble 1949) and Britain with British Honduras through Jamaica (Craig 1969). The interest in an interoceanic canal through Panama or Nicaragua expanded the United States' military and naval presence (Fig. 8), especially in Haiti, Nicaragua, and Panama (Bosch 2009:7-11; Mahan 1890, 2012 [1890]). Other factors increasing navigation in the archipelago were the massive guano deposits resulting in the Guano Island Act of 1856 (Burnett 2005; Ratter 2018: 100-101) and other countries' interests as Japan due to its proximity to the Panama Canal. (Alexandria Gazette 1913:4; New-York Tribune 1913:2; Washington Herald 1913:4).

In seeking to analyze when hurricanes are most prevalent, it is clear that September is the month with peak activity (Fig. 9). Research indicates, however, that a correlation of shipwrecks to hurricanes occurred in November, with five cases resulting from hurricanes in 1605 alone. February saw the same number of shipwrecks, but these are over the entire period (Fig. 9). Perhaps the most striking result is from the number of shipwrecks that occurred outside the regular Atlantic hurricane season. The incidents involving the Aguan and USS Kearsarge, (both in February) and the Golden Rule (in the month of May) were associated with regional geomorphology, cold fronts, strong currents, and extreme wave heights in the Caribbean Sea (Burns 1894:680; New York Times 1891a, b, c:9; New York Times 1894c:9; Ortiz-Royero et al. 2013:2798). Unfortunately, due to the restricted and ambiguous information on most of the shipwreck findings, it was impossible to determine the causes of most marine accidents. 


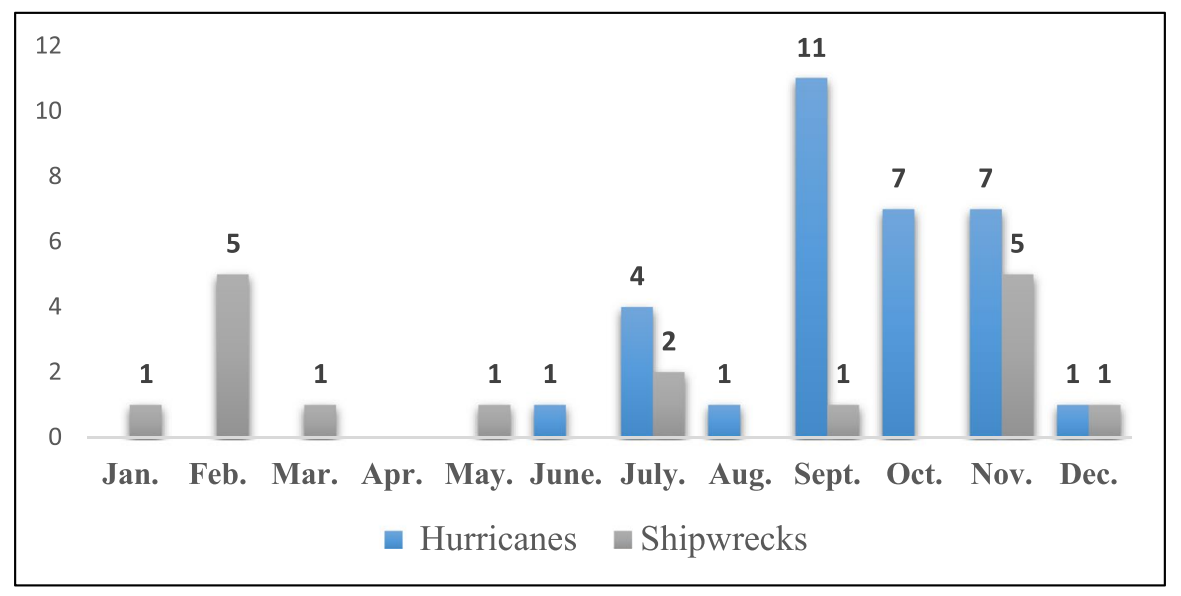

Fig. 9 Frequency of detected hurricanes and shipwrecks by months, 1492-1920. Information on months in years before 1850 is not accurate or available for both events

\section{Concluding Remarks}

This article compiled the search results for shipwrecks considering underwater cultural heritage (UCH) and hurricanes from 1492 to 1920 and its relationship, highlighting the importance of $\mathrm{UCH}$ as an indicator of the active maritime past, reflecting sociocultural processes, technological advances, independence of Spanish colonies, and the American imperialism in the Caribbean (Brauer 1988).

Different sources were analyzed with results of 23 marine accidents in Roncador Cay, providing information on 16 unrecorded shipwrecks and reviewing seven shipwrecks previously recorded by different authors. Information on hurricanes showed an outcome of 37 tropical cyclones near Roncador Cay and the archipelago waters. The research detected a lack of information and toponymical problems (Parsons 1956), especially before the nineteenth century. For this reason, some accidents were documented in an "Area of Uncertainty," near Roncador Cay, as the archipelago is comprised of many banks and cays, making the identification of sites difficult.

Information obtained from 1700 to 1800 clearly showed interruptions in maritime trade with no evidence of shipwrecks on the cay as a result of war, with most of the accidents located near Portobello or Cartagena de Indias (Kupperman 1993:355; Martin et al. 2020; Phillips 2007; Phillips et al. 2008)

Despite storm activity and hurricanes being considered leading causes of Spanish shipwrecks during colonial times in the Caribbean, most accidents compiled occurred by unspecific causes with no direct relationship to hurricanes. Nevertheless, shipwrecks were influenced by environmental conditions, such as regional geomorphology, severe weather events, or currents (Luckman 2019:104-106). Consequently, a lighthouse was placed in Roncador Cay in June 1919 by the United States Government to avoid this area's danger (Nicaragua v. Colombia 2008:160; US Department of Commerce, Light House Service 1923: 85). 
This research indicates strong evidence of numerous marine accidents caused by cold front weather conditions (Ortiz-Royero et al. 2013) and regional geomorphology as primary factors of shipwreck concentration in the archipelagic waters. Therefore, this area should be recognized as a trap for vessels (Gould 2011:82-83; Throckmorton 1964:51-61) with evidence of shipwrecks on other islands, cays, and banks, found during this study, which needs to be reviewed in detail (Gilly 1857; Hocking 1969; Lemaitre 1993:237; Marx 1987; Perez 2019; Portland Daily Press 1877:2; Romero and Perez 2005; Sandz and Marx 2006; Nautical Magazine 1835: 435-436).

Acknowledgments This research was supported by the National Research Foundation of Korea Grant funded by the Korean Government (NRF-2018S1A6A3A01081098). During this research, a category five hurricane named "Iota" impacted on November 15, 2020, Old Providence Island and Santa Catalina destroying more than $90 \%$ of the infrastructure. Iota caused the death of Nicasio Howard, a local fisherman who was helping us with information about the USS Kearsarge. Special thanks to Dr. Robert Neyland and Agustin Ortiz from the Naval History and Heritage Command-Underwater Archaeology Branch (Department of the Navy, USA) for their support with the USS Kearsarge's records from the National Archives in Washington, D.C., and Professor Camilo Rodriguez-Gutierrez for his contributions in the methodology.

Author contributions All authors contributed to the study conception and design. Material preparation, data collection and analysis were performed byWilliam Gomez Pretel and Moon-Soo Jeong. The first draft of the manuscript was written by William Gomez Pretel and Moon-Soo Jeong commented on previous versions of the manuscript. All authors read and approved the final manuscript.

\section{Declarations}

Conflict of Interest The authors declares that they have no conflict of interest.

Open Access This article is licensed under a Creative Commons Attribution 4.0 International License, which permits use, sharing, adaptation, distribution and reproduction in any medium or format, as long as you give appropriate credit to the original author(s) and the source, provide a link to the Creative Commons licence, and indicate if changes were made. The images or other third party material in this article are included in the article's Creative Commons licence, unless indicated otherwise in a credit line to the material. If material is not included in the article's Creative Commons licence and your intended use is not permitted by statutory regulation or exceeds the permitted use, you will need to obtain permission directly from the copyright holder. To view a copy of this licence, visit http://creativecommons.org/licen ses/by/4.0/.

\section{References}

Alexandria Gazette. (1913). Aggressive Japanese again in evidence. Chronicling America: Historic American Newspapers. Library of Congress, p. 4. https://chroniclingamerica.loc.gov/lccn/sn850 25007/1913-04-30/ed-1/seq-4/. Accessed March 2020.

Allen, B. (1841). Sketch of the eastern coast of Central America, compiled from notes of Captain Richard Owen and the Officers of Her Majesty's Ship Thunder, and Schooner Lark. Journal of the Royal Geographical Society of London 11:76-89.

American Seamen's Friend Society. (1853). Disasters. The Sailor's Magazine, and Naval Journal, Volume 25. Society Office. New York.

Andrade, A. (2001). Las corrientes superficiales en la cuenca de Colombia observadas con boyas de deriva. Revista de la Academia Colombiana de Ciencias Exactas, Físicas y Naturales 25(96): 321-336. 
Andrade, C. A. and Barton, E. D. (2000). Eddy development and motion in the Caribbean Sea. Journal of Geophysical Research: Oceans 105(C11):26191-26201.

Ariza, A., Melgarejo, O. J. R., Serrato, P. K., and Rincón, H. A. L. (2018). Uso de índices espectrales derivados de sensores remotos para la caracterización geomorfológica en zonas insulares del Caribe colombiano. Perspectiva Geográfica 23(1):105-122.

Bard, S. A. (1855). Waikna; or, Adventures on the Mosquito Shore. Harper \& Brothers, New York.

Bosch, J. (2009). De Cristóbal Colón a Fidel Castro: El Caribe Frontera Imperial. Cámara de Diputados, LX Legislatura; Embajada de la República Dominicana en México; Miguel Ángel Porrúa. México, D. F.

Brauer, K. (1988). The United States and British imperial expansion, 1815-60. Diplomatic History 12(1):19-37.

Bryman, A. (2003). Quantity and Quality in Social Research. Routledge, London.

Burnett, C. D. (2005). The edges of empire and the limits of sovereignty: American Guano Islands. American Quarterly 57(3):779-803.

Burns, W. (1894). The Wreck of the Kearsarge: A Narrative. Proceeding of the US Naval Institute 21(72):672-690.

Cabrera de Córdoba, L. (1857). Relaciones de las Cosas Sucedidas en la Corte de España, Desde 1599 Hasta 1614. J. Martin Alegria, Madrid.

Canney, D. (1990). The Old Steam Navy: Volume One, Frigates, Sloops, and Gunboats, 1815-1885. Naval Institute Press, Annapolis, MD.

Cerezo, R. (2001). El poder marítimo y la defensa de las comunicaciones oceánicas y de las indias occidentales. Cuadernos Monográficos del Instituto de Historia y Cultura Naval 39:89-127.

Chenoweth, M. (2006). A reassessment of historical Atlantic Basin tropical cyclone activity, 1700-1855. Climatic Change 76:169-240.

Cochran Jr., D. M. (2012). Using historical newspaper accounts to reconstruct the impacts of eighteenth century hurricanes in Central America. FOCUS on Geography 55(3):90-100.

Coralina-Invemar. (2012). Atlas De La Reserva De Biósfera SeaFlower. Archipiélago De San Andrés, Providencia Y Santa Catalina. Instituto De Investigaciones Marinas Y Costeras "José Benito Vives De Andréis" INVEMAR- Y Corporación para el Desarrollo Sostenible Del Archipiélago De San Andrés, Providencia Y Santa Catalina -CORALINA-. Serie De Publicaciones Especiales De INVEMAR \# 28. Santa Marta, Colombia.

Coventry Herald. (1837). Deaths British Library. The British Newspaper Archive, p.4. https://www.briti shnewspaperarchive.co.uk/viewer/b1/0000384/18371201/031/0004. Accessed October 2020.

Craig, A. (1969). Logwood as a factor in the settlement of British Honduras. Caribbean Studies 9(1):53-62.

Cultural Heritage Agency. (2020). Data on Underwater Cultural Heritage. Maritime Heritage. https:// english.cultureelerfgoed.nl/topics/maritime-heritage/data-on-underwater-cultural-heritage. Accessed September 2020.

Curtin, P. D. and Klein, H. S. (1973). Slave movement: records of slave ship movement between Africa and the Americas, 1817-1843. Data set. University of Wisconsin-Madison. Data and Information Services Center. Code: Name of Vessel - Columns: 15-17. https://doi.org/10.35013/JY7P-KH37

Davis, R. (1973). The Rise of the Atlantic Economies. Cornell University Press, Ithaca, NY.

Dawson, L. S. (1885). Memoirs of Hydrography: Including Brief Biographies of the Principal Officers Who Have Served in HM Naval Surveying Service between the Years 1750 and 1885. Henry W. Keay, Eastbourne.

Gaspar de Palacios. (1688). Isla misteriosa hallada por Simón Zacarías entre Cuba y Cartagena de Indias, cerca de la isla de Pinos en $18^{\circ}$ y 50'. Informe sobre ese asunto dado por el almirante Gaspar de Palacios, en Puerto de Santa María el 23 de octubre de 1688, y remitidos al marqués de los Vélez, presidente del Consejo de Indias con carta del conde de la Calzada. Isla de León, 25 de octubre de 1688. Archivo General de Indias-AGI. Catálogo De Mapas Y Planos De Santo Domingo. Indiferente, 2699, N.10. Reference Number Mp-Santo_Domingo, 89.

De Tankerville, R. (1920). "Nauticus": A Journal of Shipping, Insurance, Investments and Engineering11. Nauticus, New York.

De Velasco, J. L. (1894). Geografía y descripción universal de las Indias. Establ. tip. de Fortanet.

Diario Oficial de Colombia. (2013). Ley 1675 de 2013, por medio de la cual se reglamentan los artículos 63, 70 y 72 de la Constitución Política de Colombia en lo relativo al Patrimonio Cultural Sumergido. República de Colombia. 
Díaz Blanco, J. M. (2018). La Carrera de Indias (1650-1700): Continuidades, rupturas, replanteamientos. e-Spania. Revue interdisciplinaire d'études hispaniques médiévales et modernes 29. https://doi.org/ 10.4000/e-spania.27539.

DIMAR-Dirección General Marítima. (2005). Atlas Cartográfico de los Océanos y Costas de Colombia. Dirección General Marítima, Bogotá.

Domènech, C. (2020). La creación de un náufrago llamado Pedro Serrano: una historia intercalada en los Comentarios reales de los Incas. Bulletin of Hispanic Studies 97(2):171-187.

Domínguez, C., Salcedo, H., and Martín-Merás, L. (2012). Derrotero y Cartografía de la Expedición Fidalgo por el Caribe Neogranadino (1792-1810). El Áncora Editores, Bogotá.

Dudley, W. S. (1998). American naval archaeology: past and prologue. In Babits, L. E. and Van-Tilburg, H. (eds.), Maritime Archaeology: A Reader of Substantive and Theoretical. Contributions. Plenum Press, New York, pp.105-109.

Evening World. (1891). Miller is safe. New York, NY. Chronicling America: Historic American Newspapers. Library of Congress, p. 1. https://chroniclingamerica.loc.gov/lccn/sn83030193/1891-04-04/ ed-2/seq-1/. Accessed October 2020.

Feiling, T. (2018). The Island That Disappeared: The Lost History of the Mayflower's Sister Ship and its Rival Puritan Colony. Melville House, New York.

Fernández-Duro, C. (1897). Armada española desde la unión de los reinos de Castilla y de León, Volume 3. Est. tipográfico Sucesores de Rivadeneyra, España.

Fernández-Duro, C. (1899). Armada Española desde la Unión de los Reinos de Castilla y de León, Volume 5. Est. tipográfico Sucesores de Rivadeneyra, España.

Fernández-Duro, C. (2009 [1867]). Naufragios de la Armada Española. Relación histórica formada con presencia de los documentos oficiales que existen en el archivo del Ministerio de Marina, Sevilla, Editorial Renacimiento.

Fernández-Partagás, J. and Diaz, H. F. (1996). Atlantic hurricanes in the second half of the nineteenth century. Bulletin of the American Meteorological Society 77(12):2899-2906.

Foreign and Commonwealth Office. (1837). Corresponded with the British Commission: Sierra Leona, The Havana, Rio de Janeiro, and Surinam. Relating to the Slave Trade. Clowes and Son, London.

Garay, J., Castillo, F., and Andrade, C. (1988). Estudio oceanográfico del área insular y océanica del Caribe colombiano-Archipíelago de San Andrés y Providencia y cayos vecino. Boletín científico CIOH 9: 3-73.

García-Herrera, R., Gimeno, L., Ribera, L., and Hernadez, E. (2005). New records of Atlantic hurricanes from Spanish documentary sources. Journal of Geophysical Research: Atmospheres 110(D3); https://doi.org/10.1029/2004JD005272.

García-Herrera, R., Gimeno, L., and Ribera, P. (2007). Identification of Caribbean basin hurricanes from Spanish documentary sources. Climatic Change 83: 55-85.

Geister, J. and Díaz, J. M. (2007). Ambientes Arrecifales y Geología de un Archipiélago Oceánico: San Andrés, Providencia y Santa Catalina (Mar Caribe, Colombia) con Guía de Campo. Ingeominas, Bogotá.

Gilly, W. O. (1857). Narratives of Shipwrecks of the Royal Navy between 1793 and 1857: Compiled Principally from Official Documents in the Admiralty. John W. Parker, London.

Gomez, W. and Carvajal, A. (2011). Estrategia para la Defensa y Ubicación de las Fortificaciones de la Plaza Fuerte de Cartagena de Indias en el Siglo XVIII. A partir de condiciones océano-atmósfera y variaciones morfológicas en la línea de costa. Saber, Ciencia Y Libertad 6(2):179-192.

Gomez-Pretel, W. and Jeong, M. S. (2020). Shipwreck in the Caribbean Sea: analysis in the loss of the USS Kearsarge-Roncador Cay, Colombia (1894). Journal of Marine and Island Cultures 9(2):14-21.

Gould, R. A. (2011). Archaeology and the Social History of Ships. Cambridge University Press, Cambridge.

Guérout, M. (1988). The engagement between the CSS Alabama and the USS Kearsarge May 19, 1864: the archeological discovery, 1984-1988. Mariner's Mirror 74(4):355-359.

Harper's Weekly. (1865). Wreck of the Golden Rule IX. No 445, New York, p. 420. https://quod.lib. umich.edu/cgi/h/harpersweekly/harpersweekly-idx?coll=harpersweekly;idno=harpers. 18650708. Accessed October 2020.

Hernández Oliva, C. A. (2009). Naufragios: Barcos Españoles en Aguas de Cuba: Siglos XVI y XVII. Renacimiento, España.

Herrera y Tordesillas, A. (1601). Historia General de los Hechos de los Castellanos en las Islas i Tierra Firme del Mar Oceano. Descripción de las Indias Occidentales, tomo I. De la navegación de las 
Indias. En la Emplenta Real, Madrid.Herrera y Tordesilla, A. (1730). Historia General de los Hechos de los Castellanos en las Islas i Tierra Firme del Mar Oceano. Decada Sexta. En la oficina Real de Nicolas Rodriguez, Madrid.

Heyerman, O. (1894a). Logbook of the USS Kearsarge. 1-28-1894 to 2-1-1894. RG 24: Records of the Bureau of Naval Personnel. Log of US Naval Ships, 1801-1915. E-118. PI-1123. Vol 64. National Archives, Washington, DC.

Heyerman, O. (1894b). Report from O. F. Heyerman to Commander in Chief of US Naval Force. North Atlantic. Roncador Island. RG 125. Record of a Court of Inquiry. Exhibit. Navy Court of Inquiry. Entry 30-A.File No, 4854. USS Kearsarge (Green Box). National Archives, Washington, DC.

Hobson, H. S. (1894). The Famous Cruise of the Kearsarge: An Authentic Account in Verse of the Battle with the "Alabama" off Cherbourg, France, on Sunday, June 19, 1864. The author, Bonds Village, MA.

Hocking, C. (1969). Dictionary of Disasters at Sea during the Age of Steam: Including Sailing Ships and Ships of War Lost in Action, 1824-1962. Lloyd's Register of Shipping, London.

Hopkins, C. T. (1877). California Wreck Register, for 1871 to 1876, Inclusive. Statement and Apportionment of Marine Disasters upon Arrivals and Departures in the California Trade for the Year 1865. Bacon, San Francisco.

House Divided: The Civil War Research Engine at Dickinson College. (2015a). Loss of the Central American Transit Company's steamship Golden Rule, Capt. Dennis, on Roncador Reef, Caribbean Sea, artist's impression. Frank Leslie's Illustrated Newspaper, July 15, 1865, p. 265. http://hd.house divided.dickinson.edu/node/44142.

House Divided: The Civil War Research Engine at Dickinson College. (2015b). Survivors of the wreck of the steamer "Golden Rule," on Caribbean coral island of El Roncador, May 1865, artist's impression. Harper's Weekly Magazine, July 8, 1865, p. 420. http://hd.housedivided.dickinson.edu/node/ 44063. Accessed November 2020.

House of Commons. (1828). Slave Trade Papers Relating to the Slave Trade. Session January 29 July 28, 1828. Volume 26.

Hoyt, S. D. (1984). The archaeological survey of Pedro Bank, Jamaica, 1981-1983. International Journal of Nautical Archaeology 13:99-111.

Idárraga-García, J. and León, H. (2019). Unraveling the Underwater Morphological Features of Roncador Bank, Archipelago of San Andres, Providencia and Santa Catalina (Colombian Caribbean). Frontiers in Marine Science. https://doi.org/10.3389/fmars.2019.00077.

Jameson, J. (2010 [1923]). Privateering and Piracy in the Colonial Period: Illustrative Documents. https://www.gutenberg.org/ebooks/24882.

Johnson, C. and Hart, E. H. (1894). USS Kearsarge on Roncador Reef: Caribbean Sea, ca. 1894. (Photograph). Library of Congress. https://www.loc.gov/item/2016807822/. Accessed October 2020.

Juan, M. (1782). Relación del Viaje que Hizo el Maestre Juan (o Pedro Serrano) tras el Naufragio en la Isla de la Serrana en los Ocho Años que estuvo ella (Copia de Muñoz). Código de referencia: BMDB20160045338. Volumen y soporte de unidad de descripción: $4 \mathrm{~h}$. folio (numeradas 68-71). Copia Digital. Huracanes. Biblioteca Virtual de Defensa, España. https://bibliotecavirtual. defensa.gob.es/BVMDefensa/exp_pacifico/es/consulta/registro.do?control=BMDB20160045338. Accessed October 2020.

Kemble, J. (1949). The gold rush by Panama, 1848-1851. Pacific Historical Review 18(1):45-56.

Kennedy, P. M. (1971). Imperial Cable Communications and Strategy, 1870-19141. English Historical Review 86:728-752.

Kupperman, K. (1993). Providence Island, 1630-1641: The Other Puritan Colony. Cambridge University Press, Cambridge.

Larn, R. and Larn, B. (1997). Shipwreck Index of the British Isles: Index to Volume 1. Lloyd's Register of Shipping, London.

Lemaitre, E. (1993). Panamá y su Separación de Colombia. Amazonas Editores, Bogota.

Lemly, S. (1894). Report of the Judge Advocates General of the Navy to the Secretary of the Navy. RG 125. Record of a Court of Inquiry. Exhibit. Navy Court of Inquiry. Entry 30-A. File No. 4854. USS Kearsarge. National Archives, Washington, DC.

Leshikar-Denton, M. E. (2002). Problems and progress in the Caribbean. In Ruppe, C. and Barstad, J. (eds.), International Handbook of Underwater Archaeology. Kluwer Academic/Plenum, New York, pp. 279-298. 
Lloyd's Register Casualty Returns. (1891). Lloyd's Register of British and Foreign Shipping. Returns of Vessels Totally Lost, Condemned, \&c. 1st January to 31st March, 1891. https://hec.Irfoundation. org.uk/archive-library/casualty-returns. Accessed September 2020.

Lloyd's Register Casualty Returns. (1902). Lloyd's Register of British and Foreign Shipping. Returns of Vessels Totally Lost, Condemned, \&c. 1st October to 31st December, 1902. https://hec.lrfoundati on.org.uk/archive-library/casualty-returns. Accessed September 2020.

Lloyd's Register Casualty Returns. (1904). Lloyd's Register of British and Foreign Shipping. Returns of Vessels Totally Lost, Condemned, \&c. 1st October to 31st December, 1904. https://hec.lrfoundati on.org.uk/archive-library/casualty-returns. Accessed September 2020.

Lloyd's Register Casualty Returns. (1920). Lloyd's Register of Shipping. Returns of Vessels Totally Lost, Condemned, \&c. 1st January to 31st March, 1920. https://hec.lrfoundation.org.uk/archive-library/ casualty-returns. Accessed September 2020.

Lloyd's Register of Ships. (1835). Annual Surveys Report for Clarendon, November 17, 1835. Clarendon. Unique reference code LRF-PUN-LON598-0332a-R. Document type, Survey Office, London. https://hec.lrfoundation.org.uk/archive-library/documents/lrf-pun-lon598-0332a-r. Accessed September 2020.

Lloyd's Register of Ships. (1887). Annual Surveys Report for1835, February 15, 1887. Unique reference code, LRF-PUN-GLS153-0123-R. Document type, Survey Office, Glasgow. https://hec.lrfoundati on.org.uk/archive-library/documents/lrf-pun-gls153-0123-r. Accessed September 2020.

Lloyd's Register of Ships. (1897). Report of Survey for Repairs, \&c. for Buckingham, April 9, 1897. Unique reference code: LRF-PUN-LON712-0211-R. Document type. Survey Office, London. https://hec.lrfoundation.org.uk/archive-library/documents/lrf-pun-lon712-0211-r. Accessed September 2020.

Lovejoy, H. (2016). The registers of liberated Africans of the Havana Slave Trade Commission: implementation and policy, 1824-1841. Slavery \& Abolition 37(1):23-44.

Luckman, G. (2019). Understanding the meaning of shipwreck: the relationships between cultural and environmental influences in North-Eastern Australia. Historic Environment 31(2):102-113.

Lugo-Fernández, A., Ball, D. A., and Gravois, M. (2007). Analysis of the Gulf of Mexico's VeracruzHavana Route of La Flota de la Nueva España. Journal of Maritime Archaeology 2:24-47.

Mahan, A. T. (1890). The United States looking outward. Atlantic Monthly, pp. 4-5.

Mahan, A. T. (2012 [1890]). The Influence of Sea Power upon History, 1660-1783. Dover, New York.

Márquez, L. R. C. (2018). Arqueologia maritima en México. Revista de Arqueología Histórica Argentina y Latinoamericana 12(1):37-68.

Martin, J., Espinosa, J., and Hanselmann, F. (2020). Una mirada crítica a la arqueología marítima en Colombia: apuntes sobre algunos pecios y restos de la batalla por Cartagena de indias en 1741 . Magallánica: revista de historia moderna 6(11):203-237.

Marvel, W. (2007). The Alabama and the Kearsarge: The Sailor's Civil War. The University of North Carolina Press, Chapel Hill.

Marx, R. (1987). Shipwrecks in the Americas. Dover, New York.

MAST- Maritime Archaeology Sea Trust. (2020). Royal Navy Loss List searchable database. https://thisi smast.org/research/royal-navy-loss-list-search.html. Accessed September 2020.

McGuinness, A. (2008). Path of Empire: Panama and the California Gold Rush. Cornell University Press, Ithaca, NY.

Millas, J. (1968). Hurricanes of the Caribbean and Adjacent Regions, 1492-1800. Academy of the Arts and Sciences of the Americas, Ann Arbor, MI.

Milliman, J. D. (1969). Four southwestern Caribbean atolls: Courtown Cays, Albuquerque Cays, Roncador Bank and Serrana Bank. Atoll Research Bulletin 129. Smithsonian Institution, Washington, DC.

Missionary Herald. (1865). Letter from the Mission. Letter from Mr. Doane, June 9, 1865. Shipwreck. T. R. Marvin and Son, Boston, pp. 231-232.

Morning News. (1890a). The Ydun Wrecked. Savannah, Ga. Chronicling America: Historic American Newspapers. Library of Congress, p. 8. https://chroniclingamerica.loc.gov/lccn/sn86063034/ 1890-02-20/ed-1/seq-8/. Accessed October 2020.

Morning News. (1890b). Wreck of the Ydun Savannah, Ga. Chronicling America: Historic American Newspapers. Library of Congress, p. 3. https://chroniclingamerica.loc.gov/lccn/sn86063034/ 1890-03-12/ed-1/seq-3/. Accessed September 2020. 
Mountain Sentinel. (1852). The American Schooner Clarendon. Chronicling America: Historic American Newspapers. Library of Congress, p. 1. https://chroniclingamerica.loc.gov/lccn/sn860 71377/1852-04-22/ed-1/seq-1/. Accessed October 2020.

Mow, J. M., Howard, M., and Delgado, C. M. (2003). Promoting sustainable development: a case study of the Seaflower Biosphere Reserve. PROSPECTS 33: 303-312.

National Library of Scotland. (2020). Admiralty Charts of Scottish coasts, 1795-1963. https://maps. nls.uk/coasts/admiralty_charts_info.html. Accessed November 2020.

Naval Historical Center. (1976). Dictionary of American Naval Fighting Ships. Department of the Navy, Washington DC.

Naylor, S. (2015). Logbooks and the law of storms: maritime meteorology and the British Admiralty in the nineteenth century. Isis 106(4):771-797.

New York Herald. (1870). Marine Disasters. Chronicling America: Historic American Newspapers. Library of Congress, p. 10. https://chroniclingamerica.loc.gov/lccn/sn83030313/1870-07-26/ ed-1/seq-10/. Accessed September 2020.

New York Times. (1852). Salvage. II. No 326, p. 1. https://timesmachine.nytimes.com/timesmachine/ 1852/10/04/issue.html. Accessed March 2020.

New York Times. (1865). Ocean Steamship Lost. Wreck of the Golden Rule in the Gulf of Mexico, p. 5. https://timesmachine.nytimes.com/timesmachine/1865/06/26/80309547.html?pageN umber $=2$.

New York Times. (1886). A Shipwrecked Crew, p. 5. https://timesmachine.nytimes.com/timesmachine/ 1886/02/25/103098098.html?pageNumber=5.

New York Times. (1891a). Warner Miller on a Reef. His Nicaraguan Journey Enlivened by Shipwreck. The Steamship Aguan Stranded on The Coral Reef of a Caribbean Sea Island - All The Passengers Were Saved, p, 1. https://timesmachine.nytimes.com/timesmachine/1891/04/03/10330 0850.html?pageNumber=1. Accessed March 2020.

New York Times. (1891b). The Wreck of the Aguan. Warner Miller and Party Reach Greytown. Five Days on Roncador's Coral Reef, p. 1. https://timesmachine.nytimes.com/timesmachine/1891/ 04/05/103301120.html?pageNumber=1. Accessed March 2020.

New York Times. (1891c). The Story of the Wreck. How the Aguan went ashore and was abandoned, p. 9. https://timesmachine.nytimes.com/timesmachine/1891/04/15/issue.html. Accessed March 2020.

New York Times. (1894a). The Old Kearsarge Wreck. Strike on Roncador Reef while going to Nicaragua, pp. 1-2. https://timesmachine.nytimes.com/timesmachine/1894/02/09/issue.html. accessed March 2020.

New York Times. (1894b). A Locality Mariners Detest. Roncador Reef Famous for Wrecks. Warner Miller Came to Grief There, p. 2. https://timesmachine.nytimes.com/timesmachine/1894/02/09/ 106866929.html?pageNumber=2. Accessed March 2020.

New York Times. (1894c). Treacherous currents of Roncador. Lieut. Lyman Wishes the City of Para's Officers to Testify as to Them, p. 9. https://timesmachine.nytimes.com/timesmachine/1894/03/ 04/issue.html. Accessed March 2020.

New York Times. (1902). Ashore on Runcador Reef, p. 6. https://timesmachine.nytimes.com/times machine/1902/12/08/issue.html. Accessed March 2020.

Newton, A. (1914). The Colonizing Activities of the English Puritans: The Last Phase of the Elizabethan Struggle with Spain. Yale University, New Haven, CT.

New-York Daily Tribune. (1852). Disasters, \&c. Chronicling America: Historic American Newspapers. Library of Congress, p. 8. https://chroniclingamerica.loc.gov/lccn/sn83030213/1852-0412/ed-1/seq-8/. Accessed September 2020.

New-York Tribune. (1886). The Blizzard's Wild March. New York. Chronicling America: Historic American Newspapers. Library of Congress, p. 3. https://chroniclingamerica.loc.gov/lccn/sn83030214/ 1886-02-26/ed-1/seq-3/. Accessed October 2020.

New-York Tribune. (1902). Hard on Roncador Reef. Assistance Sent to the Fruit Company's Steamer Kitty. Library of Congress, No 20.476, p. 2. https://www.loc.gov/item/sn83030214/1902-12-08/ ed-1/. Accessed October 2020.

New-York Tribune. (1913). Japan seek Atlantic Station. After Roncador Island. Chronicling America: Historic American Newspapers. Library of Congress, p, 2. https://chroniclingamerica.loc.gov/lccn/ sn83030214/1913-04-30/ed-1/seq-2/. Accessed October 2020. 
Nicaragua v. Colombia. (2008). International Court of Justice. Counter-Memorial of Colombia. Territorial and Maritime Dispute. Volume I, pp. 26, 160. https://www.icj-cij.org/en/case/124. Accessed March 2020.

NOAA- National Oceanic and Atmospheric Administration. (2020). Historical Hurricanes Tracks. Explore more than 150 years of historical hurricane landfalls. Caribbean Sea, Roncador. https:// oceanservice.noaa.gov/news/historical-hurricanes/.

Northern Daily Times. (1857). Maritime Extract. British Library, p. 8. https://www.britishnewspaperarch ive.co.uk/viewer/bl/0002084/18571021/142/0008. Accessed October 2020.

Olien, M. (1988). Were the Miskito Indians Black? ethnicity, politics, and plagiarism in the mid-nineteenth century. Nieuwe West-Indische Gids / New West Indian Guide 62:27-50.

Ortiz-Royero, J. C. (2007). Huracanes y tormentas tropicales en el Mar Caribe colombiano desde 1900. Boletín científico $\mathrm{CIOH}$ 25:54-60.

Ortiz-Royero, J. C. (2012). Exposure of the Colombian Caribbean coast, including San Andrés Island, to tropical storms and hurricanes, 1900-2010. Natural Hazards 61:815-827.

Ortiz-Royero, J. C., Otero, L., and Restrepo, J. C. (2013). Cold fronts in the Colombian Caribbean Sea and their relationship to extreme wave events, Natural Hazards 13:2797-2804.

Pajuelo, V. (2019). Un acercamiento a la Armada del general Luis Fernández de Córdoba y Sotomayor (1602-1605). In Martínez, A. and Luque, M. (eds.), América: Problemas y Posibilidades: Segunda Parte: Descubrimientos, Exploraciones y Viajes 1:179-196.

Parsons, J. J. (1956). San Andrés and Providencia: English-Speaking Islands in the Western Caribbean. University of California Press, Berkeley.

Perez, J. (2019). Naufragios coloniales del Caribe colombiano: consideraciones investigativas, políticas y patrimoniales. Memorias 38:7-45.

Pérez-Mallaina, P. (1997). El Hombre Frente al Mar: Naufragios en la Carrera de Indias Durante los siglos XVI y XVII. 2nd. ed. Universidad de Sevilla, España.

Phillips, C. R. (2007). The Treasure of the San José: Death at Sea in the War of the Spanish Succession. Johns Hopkins University Press, Baltimore, MD.

Phillips, C. R., Hattendorf, J. B., and Beall, T. R. (2008). The sinking of the galleon San José on June 8, 1708: an exercise in historical detective work. The Mariner's Mirror 94 (2):176-187.

Plazas, J. M., Ortiz-Royero, J. C., and Lizano, R. (2011). Evaluación de la actividad ciclónica y el impacto del oleaje en la Isla de San Andrés, desde 1851 hasta 2010. Boletín Científico CIOH 29: $8-26$.

Poey, A. (1855). A Chronological Table, Comprising 400 Cyclonic Hurricanes Which Have Occurred in the West Indies and in the North Atlantic within 362 Years, from 1493 to 1855. Journal of the Royal Geographical Society of London 25:291-328.

Portland Daily Press. (1877). Memoranda. Portland, Me. Chronicling America: Historic American Newspapers. Library of Congress, p. 2. https://chroniclingamerica.loc.gov/lccn/sn83016025/187702-21/ed-1/seq-1/. Accessed December 2020.

Purdy, J. (1825). Memoir, Descriptive and Explanatory: To Accompany the New Chart of the Atlantic Ocean and Comprising Instructions, General and Particular, for the Navigation of that Sea. 5th ed. R. H Laurie, London.

Rappaport, E. N. and Fernández-Partagás, J. (1995). The deadliest Atlantic tropical cyclones, 1492-1994. NOAA Technical Memorandum NWS NHC-47. National Hurricane Center, Miami, FL.

Rappaport, E. N. and Fernández-Partagás J. (1997). History of the deadliest Atlantic tropical cyclones since the discovery of the New World. In Diaz, H. F. and Pulwarty, R. S. (eds.), Hurricanes. Springer, Berlin. https://doi.org/10.1007/978-3-642-60672-4_5

Ratter, B. M. (2018). Geography of Small Islands. Springer, New York.

Republic. (1852). Official. Chronicling America: Historic American Newspapers. Library of Congress, p. 3. https://chroniclingamerica.loc.gov/lccn/sn82014434/1852-09-30/ed-1/seq-1/. Accessed October 2020.

Richardson, P. L. (2005). Caribbean current and eddies as observed by surface drifters. Deep Sea Research Part II: Topical Studies in Oceanography 52(3-4): 429-463.

Robinson, T. (1907). Panama: A Personal Record of Forty-Six Years, 1861-1907. Star and Herald, New York.

Romero, L. and Perez, J. (2005). Naufragios y Puertos Marítimos en el Caribe Colombiano. Siglo XXI Editores, México City.

Rowland, D. (1935). Spanish occupation of the island of Old Providence, or Santa Catalina, 1641-1670. Hispanic American Historical Review 15(3):298-312. 
Sandz, V. and Marx, R. (2006). Encyclopedia of Western Atlantic Shipwrecks and Sunken Treasure. McFarland, London.

Savannah Morning News. (1886a). Memoranda. Aspinwall. Savannah. Chronicling America: Historic American Newspapers. Library of Congress, p. 7. https://chroniclingamerica.loc.gov/lccn/sn820 15137/1886-02-16/ed-1/seq-7/. Accessed October 2020.

Savannah Morning News. (1886b). Maritime Miscellany. Bark Hiram (Nor). Savannah. Chronicling America: Historic American Newspapers. Library of Congress, p.7. https://chroniclingamerica.loc. gov/lccn/sn82015137/1886-02-27/ed-1/seq-7/. Accessed October 2020.

Scotsman. (1920). Shipping Notes and Casualties. British Library. British News Paper Archive, p, 4. https://www.britishnewspaperarchive.co.uk/viewer/bl/0000540/19200127/188/0004. Accessed October 2020.

Segovia, R. (2007). La Armada de la Guardia de la Carrera de Indias de don Luis Fernández de Córdoba (1605). In: Meisel-Roca, A. and Calvo-Stevenson, H. (eds.), Cartagena de Indias en el Siglo XVII. Banco de la Republica, Colombia, pp. 158-206.

Serrano, F. (1991). Naufragios y Rescates en el Tráfico Indiano durante el Siglo XVII. Seglusa Editores. España.

Shields Daily News. (1904). British Steamer Wreck. British Library, p. 3. https://www.britishnewspape rarchive.co.uk/viewer/bl/0001168/19041214/143/0003. Accessed September 2020.

Shipbuilding and Shipping Record. (1920). A Journal of Shipbuilding, Marine Engineering, Dock, Harbours \& Shipping. Tables of Launches 15:148.

Shipping Gazette and Lloyd's List. (1890). Ydun. British News Paper Archive, p. 8. https://www.briti shnewspaperarchive.co.uk/viewer/bl/0001941/18900224/071/0008. Accessed September 2020.

Singer, S. D. (1998). Shipwrecks of Florida: A Comprehensive Listing. Pineapple Press, Sarasota, FL.

Skipshistorie. (2017). Skipshistorie. 1891 DS Kitty (UKJ101189106). https://skipshistorie.net/Fruktskip/ Tekster/UKJ10118910600000\%20KITTY.htm. Accessed September 2020.

Spears, J. (1891). Twas a Cheerful Disaster. Chronicling America: Historic American Newspapers. Library of Congress, p. 5. https://chroniclingamerica.loc.gov/lccn/sn83030272/1891-04-15/ed-1/ seq-5. Accessed October 2020.

Sutton, A. and Yingling, C. (2020). Projections of desire and design in early modern Caribbean maps. Historical Journal 63(4):789-810.

Temperley, H. (1909). The causes of the War of Jenkins' Ear, 1739. Transactions of the Royal Historical Society 3:197-236.

Nautical Magazine. (1835). The Nautical Magazine and Naval Chronicle: A Journal of Papers on Subjects Connected with Maritime Affairs. Brown and Ferguson, London.

Thomas, J. (1974). The role of private libraries and public archives in nineteenth-century Spanish American historiography. Journal of Library History 9(4):334-351.

Throckmorton, P. (1964). The Lost Ships: An Adventure in Undersea Archaeology. Little, Brown. Boston.

Trouet, V., Harley, G. L., and Domínguez-Delmás, M. (2016). Shipwreck rates reveal Caribbean tropical cyclone response to past radiative forcing. Proceedings of the National Academy of Sciences 113(12):3169-3174.

UNESCO- United Nations Educational, Scientific, and Cultural Organization. (2020). Underwater Cultural Heritage. Databases: Underwater cultural heritage sites. Regions. http://www.unesco.org/new/ en/culture/themes/underwater-cultural-heritage/underwater-cultural-heritage/databases/. Accessed September 2020.

US Department of Commerce, Light House Service. (1923). The United States Lighthouse Service 1923. Government Printing Office, Washington, DC.

US Department of State, Office of the Legal Advisor. (1932). The Sovereignty of the Islands of Roncador, Quito Sueno, Serrana, and Serranilla. Washington, DC. http://hdl.handle.net/10524/54209. Accessed April 2021.

US Hydrographic Office. (1894). US Hydrographic Office to the Bureau of Navigation. Paper relating to the position of Roncador Reef. No 454,444. Exhibit .G. 125. Record of a Court of Inquiry. Exhibit. Navy Court of Inquiry. Entry 30-A.File No, 4854. USS. Kearsarge (Green Box). National Archives, Washington, DC.

USS Kearsarge. (1894). National Archives Record Group 125, Records of the Navy Judge Advocate, Entry 31, Proceedings of Inquiry, and located the proceeding for the wreck of the USS Kearsarge, the file number is 4854, and Record Group 24, Records of the Bureau of Naval Personnel, Entry 118, Logs of US Navy Ships and located the log of the USS Kearsarge National Archives Building, Washington, DC. 
Valdés, P. (1605). December, 15. Carta de Don Pedro de Valdés, Gobernador de La Habana. Cartas De Gobernadores. Santo Domingo, 100, R.2, N.3. Reference code: ES.41091.AGI/24//SANTO_ DOMINGO,100,R.2,N.30. Archivo General de Indias, Sevilla.

Vergara y Velasco, F. J. (1888). El Archipíelago de San Andrés (las Islas de San Andrés y Providencia): Noticia Geográfica. Zalamea, Bogota.

Vigneras, L. (1962). The Cartographer Diogo Ribeiro. Imago Mundi 16:76-83.

Vizenor, G. (1991). The Heirs of Columbus. Wesleyan University Press, Middletown, CT.

Western Times. (1904). Wreck on Roncador Reef. British Library. British News Paper Archive, p. 4. https://www.britishnewspaperarchive.co.uk/viewer/bl/0000265/19041215/050/0004. Accessed October 2020.

Willoughby, H. E. and Rahn, M. E. (2004). Parametric representation of the primary hurricane vortex. Part I: Observations and evaluation of the Holland (1980) model. Monthly Weather Review 132(12):3033-3048.

Young, T. (1842). Narrative of a Residence on the Mosquito Shore, during the Years 1839, 1840, \& 1841: With an Account of Truxillo and the Adjacent Islands of Bonacca and Roatan. Smith, Elder, London.

Zapatero, J. (1990). La Guerra del Caribe en el siglo XVIII. Servicio Histórico Militar y Museo del Ejército, Madrid.

Zenkiewicz, M. and Wasilewski, T. (2019). The galleon San Jose: almost four decades of legal struggles on the national and international plane. Comparative Law Review 22:319-342.

Publisher's Note Springer Nature remains neutral with regard to jurisdictional claims in published maps and institutional affiliations. 